Cornell University

School of Industrial and Labor Relations

Center for Advanced Human Resource Studies
CAHRS at Cornell University 187 Ives Hall

Ithaca, NY 14853-3901 USA

Tel. 607 255-9358

www.ilr.cornell.edu/CAHRS

\title{
Educational Reform and Disadvantaged Students: are they better off or worse off?
}

\author{
John H. Bishop
}

Ferran Mane

Working Paper $04-13$ 


\title{
Educational Reform and Disadvantaged Students: Are They Better Off or Worse Off?
}

\author{
John H. Bishop \\ Cornell University \\ Ithaca, NY 14853 \\ Ferran Mane \\ Universitat Rovira i Virgili \\ Reus, Catalonia, Spain
}

August 2004

http://www.ilr.cornell.edu/cahrs

This paper has not undergone formal review or approval of the faculty of the ILR School. It is intended to make results of Center research available to others interested in preliminary form to encourage discussion and suggestions.

Most (if not all) of the CAHRS Working Papers are available for reading at the Catherwood Library. For information on what's available link to the Cornell Library Catalog:

http://catalog.library.cornell.edu if you wish. 


\begin{abstract}
This paper analyzes the effects of increased academic standards on both average achievement levels and on equality of opportunity. The five policies evaluated are: (1) universal Curriculum-Based External Exit Exam Systems, (2) voluntary curriculum-based external exit exam systems with partial coverage such as New York State Regents exams in 1992, (3) state minimum competency graduation tests, (4) state defined minimums for the total number of courses students must take and pass to get a high school diploma and (5) state defined minimums for the number of academic courses necessary to get a diploma. We use international data to evaluate the effects of CBEEES. High school graduation standards differ a lot across states in the U.S. This allowed us to measure policy effects on student achievement and labor market success after high school by comparing states in a multiple regression framework.

Our analysis shows that only two of the policies examined deliver on increasing everyone's achievement and also reduce achievement gaps: universal CBEEES and higher academic course graduation requirements. Other policies were less successful in raising achievement and enhancing equality of opportunity.
\end{abstract}




\section{Educational Reform and Disadvantaged Students: Are They Better Off or Worse Off?}

Political leaders in many nations are looking for ways to better prepare their youth to compete in the global economy and to help disadvantaged children catch up educationally. Education policy debates are often framed as striking a balance between the "opposing" goals of high standards and equality of opportunity. The left and the right wings of the political spectrum take sides and a stalemate ensues. While some policy choices do present a tradeoff between these goals, other policy options do not. Accountability advocates, for example, argue that strengthening school and student accountability will simultaneously raise achievement and enhance equality of opportunity. Opponents of accountability claim the reverse is true. This paper subjects these claims to rigorous empirical analysis using both international and U.S. data.

We begin in section 1 by laying out reasons for expecting high or medium stakes external assessment of student achievement to both raise achievement levels and to close gaps between advantaged and disadvantaged students. The empirical work presented in section 2 assesses the effects of student accountability by comparing the achievement levels, school attendance rates and equality of opportunity outcomes of nations that do and do not have curriculum-based external exit exam system (CBEEES) like the French Baccalaureate and Britain's GCSE and A level exams. Data on 41 countries from the year 2000 Program for International Students Assessment (PISA) are analyzed.

We next turn to an analysis of U.S. longitudinal data following a cohort of $8^{\text {th }}$ graders in 1988 through young adulthood until the year 2000. The third section of the paper describes the mechanisms by which state governments tried to make schools and students more accountable during the years National Educational Longitudinal Survey of 1988 (NELS-88) students were attending high school. The empirical work assesses the effects of four state accountability policies being employed at that time: (1) state defined minimums for the total number of courses students must take and pass to get a high school diploma; (2) state defined minimums for the number of 
academic courses necessary to get a diploma, (3) states minimum competency graduation tests and (4) a voluntary curriculum-based external exit exam system—the New York State Regents exams-covering about 60 percent of high school students. The empirical work that follows in section 4 compares these four policies to the more traditional spending oriented policies of reducing pupil-teacher ratios and increasing teacher salaries. The empirical work evaluates the impacts of these policies on test score gains, high school completion, college attendance and completion and labor market success. The models we estimate include an interaction of a parental socio-economic status composite with each of the policy variables. This allows us to calculate separate impact estimates for low SES, medium SES and high SES students. Section five presents a summary of results and proposes an agenda for future research.

\section{External Examinations: Signals of Learning that Encourage High Standards and Improve Payoffs to Learning}

Let us begin by defining what a Curriculum-Based External Examination System is and

is not. CBEEES have the following eight features:

1. Produce signals of accomplishment that have real consequences for the student.

2. Define achievement relative to an external standard, not relative to other

students in the classroom or the school. Fair comparisons of achievement across schools and across students taught by different teachers are now possible. Costrell's (1994a) analysis of the optimal setting of educational standards concluded that more centralized standard setting (state or national achievement exams) results in higher standards, higher achievement and higher social welfare than decentralized standard setting (i.e. teacher grading or schools graduation requirements).

3. Are controlled by the education authority that establishes the curriculum for and funds K-12 education. When a national or provincial ministry of education sponsors an external exam, it is more likely to be aligned with the national or provincial curriculum. It is, consequently, more likely to be used for school accountability; not just as an instrument of student accountability. Curriculum reform is facilitated because coordinated changes in instruction and exams are feasible. Tests established and mandated by other organizations-e.g. the SAT-I and the ACTserve the interests of colleges to sort students by aptitude not the needs of high schools to reward students who have learned what schools are trying to teach. 
4. Cover the vast majority of students. External exams for elite students (e.g. AP exams) raise achievement levels of these students, but they will also tend to increase achievement gaps between high SES and low SES students.

5. Assess a major portion of what students are expected to know or be able to do. Studying to prepare for an exam (whether set by one's own teacher or by a ministry of education) should result in the student learning important material and developing valued skills.

6. Are collections of End-of-Course Exams (EOCE). Since they assess the content of specific sequences of courses, alignment between instruction and assessment is maximized and teacher accountability is enhanced. Teachers become coaches helping their team do battle with the national or provincial exam. Students should be less likely to pressure teachers to lower standards.

7. Signal multiple levels of achievement in the subject. If only a pass-fail signal is generated by an exam, the standard will, for political reasons, have to be set low enough to allow almost everyone to pass. The achievement of most students will be so far above this level that the threat of failing the exam will not stimulate them to greater effort (Kang 1985; Becker and Rosen 1992; Costrell 1994; Betts and Costrell 2001). CBEEEs signal the student's achievement level in the subject, not just whether the student exceeds or falls below a specific cut point that all high school graduates are required to surpass. Consequently all students, not just those at the bottom of the class, are given an incentive to study hard to do well on the exam (Becker and Rosen 1992). Costrell agrees: "The case for perfect information [making scores on external examinations available rather than just whether the individual passed or failed] would appear to be strong, if not airtight: for most plausible degrees of heterogeneity, egalitarianism, and pooling under decentralization, perfect information not only raises GDP, but also social welfare (1994, p. 970)."

8. Assess difficult material. Since CBEEES signal the full range of achievement in the subject, they contain more difficult questions and problems. This induces teachers to spend more time on cognitively demanding skills and topics.

Systems of curriculum-based external exit examinations (CBEEES) provide a strong and organic system of accountability. Exam grades typically appear on resumes and are requested on job applications. Exam grades influence (and in some nations completely determine) whether a student can enter a university and which university and what field of study they are admitted to. Where CBEEES are absent, university admission decisions are based on multiple choice format aptitude tests that are not keyed to the courses taken in secondary school and teacher 
assessments of relative performance--rank in class and grades. In nations lacking a CBEEESSpain and the United States, for example--employers typically pay little attention to achievement in high school when making hiring decisions. CBEEES also strengthen social incentives to study because students are no longer competing with each other for a limited number or As and Bs. Everyone can get a 90 or better on the external exam, so students will be less supportive of those who disrupt the class and more supportive of those who take learning seriously. It no longer makes sense for students to avoid the more rigorous courses and the more demanding teachers.

CBEEES change how student achievement is signaled. By doing so they transform the incentives for everyone: parents, teachers and school administrators as well as students. In the U.S. locally elected school boards and administrators make the thousands of decisions that determine academic expectations and program quality. When there is no external assessment of academic achievement, students and their parents benefit little from administrative decisions that opt for higher standards, more qualified teachers or a heavier student workload. The immediate consequences of such decisions are all negative: higher local property taxes, more homework, having to repeat courses, lower GPA's, complaining parents, a greater risk of being denied a diploma.

This is one of the reasons why 30 percent of American teachers report being pressured by parents or administrators "to reduce the difficulty and amount of work you assign and "to give higher grades than students' work deserves" (Hart 1995)." When the only signal of student achievement is teacher grades, parents typically prefer high grades not high standards (Figlio and Lucas 2002). All students end up learning less. Standards fall most of all in schools serving students from disadvantaged backgrounds or with limited English proficiency. External exams prevent teachers from hiding teaching failures by lowering standards to keep failure rates low. The only response open to them is to demand more of their students so as to maximize their chances of being successful on the external exams.

Teachers who work in systems with external exams are aware of this. When a proposal 
was put forward in Ireland to drop the nation's system of external assessments and have teachers assess students for certification purposes, the union representing Ireland's secondary school teachers reacted as follows:

Major strengths of the Irish educational system have been:

(i) The pastoral contribution of teachers in relation to their pupils

(ii) The perception of the teacher by the pupil as an advocate in terms of nationally certified examinations rather than as a judge.

The introduction of school-based assessment by the pupil's own teacher for certification purposes would undermine those two roles, to the detriment of all concerned....

The role of the teacher as judge rather than advocate may lead to legal accountability in terms of marks awarded for certification purposes. This would automatically result in a distancing between the teacher, the pupil and the parent. It also opens the door to possible distortion of the results in response to either parental pressure or to pressure emanating from competition among local schools for pupils. (Association of Secondary Teachers of Ireland, Flyer, 1990, p. 1)

Note how the Irish teachers union feared that switching entirely to internal assessment would result in teachers being pressured to lower standards.

Without a CBEEES to signal achievement, the benefits of higher standards and greater effort lose visibility. Graduates will probably do better in difficult college courses and will be more likely to get a degree, but that benefit is uncertain, far in the future and not visible to parents and local voters. In this environment, administrators will seek teachers who keep their class orderly and entertained, who have roots in the community and who are willing to coach. If this is all one expects of teachers, sufficient numbers can be found at current salary levels. If, however, administrators were to demand that newly hired teachers have a deep knowledge of their subject and the ability to teach it to teenagers, they would find that there are not enough qualified teachers to go around. The shortage would not disappear until much higher salaries were offered. School 
tax levies would have to rise. External exams make stake holders care about how well high school subjects are taught. Hiring better teachers and improving the school's science laboratories now yields a visible payoff--more students passing the external exams and being admitted to top colleges. This should induce school districts to compete for talent by offering higher salaries and better working conditions. When external assessment is absent, school reputations are determined by things that teachers and administrators have little control over: the socio-economic status of the student body and the proportion of graduates going to college.

A further benefit of CBEEES is the professional development that teachers receive when they are brought to centralized locations to grade the extended answer portions of examinations. In May 1996 I interviewed teacher's union activists about diploma exams in Alberta, Canada. Even though these teachers opposed the exams, they universally reported that the grading committees were “...a wonderful professional development activity (Bob, 1996).” Having to agree on what constituted excellent, good, poor, and failing responses to essay questions or open-ended math problems resulted in a sharing of perspectives and teaching tips that most found very helpful.

CBEEES are, consequently, hypothesized to influence the priorities of school administrators, teacher pedagogy, parental encouragement, student effort and achievement. They are also expected to press school systems to raise achievement of students from disadvantaged backgrounds.

\section{International Evidence on the Effects of CBEEES}

Literature Review: The hypothesis that curriculum-based external exit examination systems improve achievement has been tested by comparing nations and provinces that do and do not have such systems. Five different international data sets have been examined. In most studies of the effect of CBEEES national mean test scores (for an age group or a grade) were regressed on per capita gross domestic product deflated by a purchasing power parity price index, a dummy for East Asian nation and a dummy for CBEEES. Analyzing 1994-95 Third International Math and Science Study (TIMSS) data, Bishop $(1996,1997)$ found that 13 year old students from 
countries with medium and high stakes CBEEE systems outperformed students from other countries at a comparable level of economic development by 1.3 U.S. grade level equivalents (GLE) in science and by 1.0 GLE in mathematics. Analysis of data from the 1990-01 International Association for the Evaluation of Educational Achievement's study of the reading literacy study of 14 year olds in 24 countries found that students in countries with CBEEES were about 1.0 GLE ahead of students in nations that lacked a CBEEES (Bishop 1999). Analysis of data from both waves of TIMSS data collection also implies that CBEEES have highly significant effects (of about 1.5 GLEs) on the math and science achievement in $8^{\text {th }}$ grade (Bishop 2003).

Two other studies (Ludger Wößmann (2000, 2002) and Hyea Sook Ryoo (2002) have conducted hierarchical analyses of the entire TIMSS and TIMSS-R micro data set and included a comprehensive set of controls for family background, teacher characteristics, school resources and policies at the individual and school level. Wößmann found that $8^{\text {th }}$ graders in CBEEES nations were about 1.1 international grade level equivalents ahead in mathematics and about 0.8 international grade level equivalents ahead in science. He also found that learning gains between $7^{\text {th }}$ and $8^{\text {th }}$ grade were significantly larger in CBEEES nations. Another two studies compare students living in different provinces/states in Germany and Canada. Wößmann found that the German Lander with centralized secondary school exit examinations had significantly higher scores on the PISA literacy assessments. Students attending school in Canadian provinces with CBEEES were a statistically significant one-half of a U.S grade level equivalent ahead in math and science of comparable students living in provinces without CBEEES (Bishop 1997, 1999a).

We will now turn to new analysis of Program for International Student Assessment 2000 data on 41 countries. The Program for International Student Assessment (PISA) is a new system of international assessments focusing on the reading, mathematics and science literacy of 15-year-olds. Each participating country selected a nationally representative sample of approximately 4000 fifteen year olds. The students completed a 20 to 30 minute background questionnaire and a 90-minute assessment consisting of a mix of multiple choice, short 
answers, and extended response questions. "While other studies, such as TIMSS and NAEP, have a strong link to curriculum frameworks and seek to measure student's mastery of specific knowledge, skills and concepts, PISA is designed to measure 'literacy' more broadly." ${ }^{1}$ PISA assesses the cumulative educational experiences of all students at age 15 regardless of the grade levels or type of institution they are attending. "By assessing students near the end of compulsory schooling in key knowledge and skills, PISA provides information about how well prepared students will be for their future lives as they approach an important transition point for education and work."2

Table 1

Academic Achievement in Nations with and without Curriculum-Based External Exit Examination Systems: Program for International Student Assessment 2000 Data

\begin{tabular}{|c|c|c|c|c|c|c|c|}
\hline Dependent Variable & $\begin{array}{c}\text { Curriculu } \\
\text { m-Based } \\
\text { External } \\
\text { Exit Exam }\end{array}$ & $\begin{array}{c}\text { Log } \\
\text { GDPI } \\
\text { Pop } \\
1995-99\end{array}$ & $\begin{array}{l}\text { East } \\
\text { Asia }\end{array}$ & $\begin{array}{c}\text { Adult } \\
\text { Unemp., } \\
\text { Rate }\end{array}$ & $\begin{array}{c}\% \text { Up Sec in } \\
\text { Voc \& Pre-voc } \\
\text { program }\end{array}$ & $\begin{array}{l}\text { Adj } R^{2} \\
\text { RMSE }\end{array}$ & $\begin{array}{l}\# \text { of } \\
\text { Obs }\end{array}$ \\
\hline $\begin{array}{l}\text { Reading--Parents Native Born - } \\
15 \text { Yr Olds }\end{array}$ & $\begin{array}{c}21.7^{* *} \\
(8.7)\end{array}$ & $\begin{array}{l}75.7^{\star \star \star} \\
(5.7)\end{array}$ & $\begin{array}{c}17.6 \\
(12.0)\end{array}$ & & & $\begin{array}{l}.821 \\
23.7\end{array}$ & 41 \\
\hline $\begin{array}{l}\text { Math-Parents Native Born } \\
-15 \text { Yr Olds }\end{array}$ & $\begin{array}{c}39.9^{* \star \star} \\
(12.1)\end{array}$ & $\begin{array}{l}84.9^{* \star \star} \\
(7.9)\end{array}$ & $\begin{array}{l}36.6^{* *} \\
(16.7)\end{array}$ & & & $\begin{array}{l}.764 \\
32.7\end{array}$ & 41 \\
\hline $\begin{array}{l}\text { Science-Parents Native Born- } \\
15 \text { Yr Olds }\end{array}$ & $\begin{array}{l}32.4^{* \star \star} \\
(9.9)\end{array}$ & $\begin{array}{l}71.3^{* \star \star} \\
(6.5)\end{array}$ & $\begin{array}{l}29.7^{* *} \\
(13.9)\end{array}$ & & & $\begin{array}{l}.756 \\
27.1\end{array}$ & 41 \\
\hline $\begin{array}{l}\text { Expected Yrs of Schooling:5-65 } \\
\text { [sum of net enrollment rates]. }\end{array}$ & $\begin{array}{l}.08 \\
(.61)\end{array}$ & $\begin{array}{c}3.34^{* \star *} \\
(.48)\end{array}$ & $\begin{array}{l}.75 \\
(.91)\end{array}$ & & & $\begin{array}{l}.611 \\
1.58\end{array}$ & 37 \\
\hline $\begin{array}{l}\text { Expected FTE Yrs of Sch:5-65 } \\
\text { [sum FTE net enrollment rates] }\end{array}$ & $\begin{array}{l}-.08 \\
(.46)\end{array}$ & $\begin{array}{c}2.98^{* * *} \\
(.36)\end{array}$ & $\begin{array}{l}.47 \\
(.69)\end{array}$ & & & $\begin{array}{l}.698 \\
1.20 \\
\end{array}$ & 37 \\
\hline $\begin{array}{l}\text { \% Graduating from Upper } \\
\text { Secondary School }\end{array}$ & $\begin{array}{l}10.4^{*} \\
(5.4)\end{array}$ & $\begin{array}{l}26.3^{* * *} \\
(5.9)\end{array}$ & $\begin{array}{c}15.3+ \\
(8.8)\end{array}$ & $\begin{array}{l}1.19+ \\
(.70)\end{array}$ & $\begin{array}{l}.26^{\star *} \\
(.12)\end{array}$ & $\begin{array}{l}.582 \\
11.0\end{array}$ & 23 \\
\hline $\begin{array}{l}\% 15-19 \text { Yr Olds Enrolled in } \\
\text { school or college }\end{array}$ & $\begin{array}{l}-2.6 \\
(4.7)\end{array}$ & $\begin{array}{l}22.0^{* \star *} \\
(5.0)\end{array}$ & $\begin{array}{c}10.4 \\
(10.6)\end{array}$ & $\begin{array}{l}1.27^{* *} \\
(.57)\end{array}$ & $\begin{array}{l}.18^{*} \\
(.10)\end{array}$ & $\begin{array}{l}.434 \\
10.1\end{array}$ & 28 \\
\hline $\begin{array}{l}\% 20-24 \text { Yr Olds Enrolled in } \\
\text { school or college }\end{array}$ & $\begin{array}{l}2.2 \\
(3.2)\end{array}$ & $\begin{array}{c}10.3^{* * *} \\
(3.4)\end{array}$ & $\begin{array}{c}4.4 \\
(7.3)\end{array}$ & $\begin{array}{l}.62+ \\
(.39)\end{array}$ & $\begin{array}{l}.02 \\
(.10)\end{array}$ & $\begin{array}{l}.434 \\
10.1 \\
\end{array}$ & 28 \\
\hline
\end{tabular}

Source: Expected years of schooling is from OECD, Education at a Glance 2001, p. 133. The full-time equivalent number counts part-time enrollment as 0.5 years. Data on PISA from Literacy Skills for the World of Tomorrow: Further Results from PISA 2000, p. 351. Data on unemployment rates in OECD countries in the United Nations' Human Development Report 2001. The model predicting the share of 15-19 and 20-29 year olds in school included: Australia, Austria, Belgium, Canada, Czech Republic, Denmark, Finland, France Germany, Greece, Hungary, Iceland, Ireland, Italy, Korea,

Luxembourg, Mexico, Netherlands, New Zealand, Norway, Portugal, Poland, Spain, Switzerland, Sweden, Turkey, United Kingdom and the United States. ${ }^{3}$ 
Achievement Levels: The first three rows of Table 1 present an analysis of PISA data on reading, mathematics and science literacy. The achievement of students with two native-born parents is analyzed in order to eliminate variation in rates of immigration as a confounding variable. The base line model has three variables: GDP per capita (to capture national wealth, the socio-economic background of parents and the efficiency of the nation's institutions), a dummy variable for CBEEES nation and a dummy variable for East Asia intended to capture cultural differences between East and West. Scores are significantly higher in more developed nations, East Asian nations and in nations with a CBEEES. Estimated impacts of CBEEES appear to be comparable to those in TIMSS and IEA reading studies and similar in magnitude to a doubling of a nation's productivity and income per capita. ${ }^{4}$

School Attendance Rates: Many believe a tradeoff exists between the standards and quality of an educational system and the number of students who can or will stay in school into their late teens and twenties. Opponents of high or medium stakes student accountability systems often argue that they will increase dropout rates and reduce college attendance rates. This hypothesis was tested by calculating how many years youth in each nation spend in school [by summing the net-enrollment rates of people from age 5 to 65 ] and then testing what impact CBEEES have on "expected years of schooling." The results are presented in the fourth and fifth rows of Table 1. CBEEES had no effect on expected years of schooling. The only variable with significant effects on the number of years people spend in school was per-capita GDP.

Rows 6 through 8 present models assessing the effects of CBEEES on upper-secondary graduation rates and school attendance rates of 15-19 year olds and 20-24 year olds. These models included controls for two additional variables previously shown to be important: unemployment and the availability of career-tech programs in upper-secondary school (Bishop and Mane 2004). Curriculum-based external exit exams had no significant association with school enrollment rates but a significant positive relationship with upper-secondary graduation rates. 
Here again the productivity level of the country_per capita GDP—was the most important predictor. The adult unemployment rate had a statistically significant positive relationship with enrollment rates and graduation rates. The share of upper-secondary students in career-tech programs also had statistically significant (at the 10 percent level on a two-tail test) positive relationships with upper secondary graduation rates and the proportion of 15-19 year olds in school or college. The relationship appears to be substantively important. A 10 percentage point increase in the share of upper secondary students in vocational and prevocational programs is associated with a 2.6 percentage point increase in the high school graduation rate and a 1.8 percentage point increase in the proportion of 15-19 year olds in school.

Inequality of Opportunity: Table 2 presents our analysis of the effects of CBEEES on three indicators of inequality of educational opportunity. An appendix of the PISA report presents simple within-country regressions in which test scores were predicted either by a family wealth index (based on student reports of home size and possessions) or by an occupational status index for the family's bread winner. Large positive parameters imply that the educational success of children strongly depends on parent SES and that educational opportunities are quite unequal. Small SES parameters imply that educational opportunities are pretty equal. These PISA estimated SES parameters become our dependent variables. Results are presented in the top panel of Table 2. If the coefficient on the CBEEES dummy in the first column is negative, the external exit exams are providing a bigger boost to the learning of students from disadvantaged backgrounds than advantaged backgrounds Positive coefficients on CBEEES imply the opposite.

All four of the coefficients are negative and three are significantly negative. This implies that CBEEES enhance the learning of disadvantaged children more than they enhance the learning of children from advantaged backgrounds. How big are these effects? The dependent variables being predicted represent the impact of a one standard deviation increase in family wealth or occupational status on test scores. In the U.S. families in the bottom quartile on the 
wealth index are on average 2.4 standard deviations below the mean for the top quartile. The regression predicts that CBEEES improve the reading literacy of the children from the bottom wealth quartile by 23 points $\left(-9.7^{\star} 2.4\right)$ more than it improves the reading literacy of students from the top wealth quartile. This compares quite favorably to our 21.7 point estimate of the average effect of a CBEEES on children of native-born parents. CBEEES are also predicted to improve math literacy of the bottom occupational status quartile by 12 points $\left(4.6^{\star} 2.6\right)$ more than for the top quartile. For science the low SES children improve 14.6 points more than high SES children when they live in a nation with CBEEES.

Table 2

Effects of Social Class on Academic Achievement in Nations with or without Curriculum-Based External Exit Examination Systems: Program for International Student Assessment 2000 Data

\begin{tabular}{|c|c|c|c|c|c|}
\hline Dependent Variable & $\begin{array}{c}\text { Curriculu } \\
\text { m-Based } \\
\text { External } \\
\text { Exit Exam }\end{array}$ & $\begin{array}{c}\text { Log } \\
\text { GDPI } \\
\text { Pop } \\
\text { 1995-99 }\end{array}$ & $\begin{array}{c}\text { Dependent } \\
\text { Variable-- } \\
\text { Mean \& } \\
\text { Std. Dev. }\end{array}$ & $\begin{array}{l}\text { Adj } R^{2} \\
\text { RMSE }\end{array}$ & $\begin{array}{l}\text { \# of } \\
\text { Obs }\end{array}$ \\
\hline $\begin{array}{l}\text { Effect of } 1 \text { Std. Dev. of Family Wealth } \\
\text { on Reading Literacy }\end{array}$ & $\begin{array}{c}-9.6^{* * *} \\
(3.0)\end{array}$ & $\begin{array}{l}-1.6 \\
(2.0)\end{array}$ & $\begin{array}{l}15.6 \\
(9.3)\end{array}$ & $\begin{array}{r}.186 \\
8.4\end{array}$ & 41 \\
\hline $\begin{array}{l}\text { Effect of } 1 \text { Std. Dev. of Socio-Economic } \\
\text { Status on Reading }\end{array}$ & $\begin{array}{l}-4.6^{*} \\
(2.5)\end{array}$ & $\begin{array}{c}1.0 \\
(1.7)\end{array}$ & $\begin{array}{l}31.0 \\
(7.3)\end{array}$ & $\begin{array}{r}.040 \\
7.1\end{array}$ & 40 \\
\hline $\begin{array}{l}\text { Effect of } 1 \text { Std. Dev. of Socio-Economic } \\
\text { Status on Mathematics }\end{array}$ & $\begin{array}{l}-5.6^{* *} \\
(2.8)\end{array}$ & $\begin{array}{c}.5 \\
(1.9)\end{array}$ & $\begin{array}{l}30.0 \\
(8.0)\end{array}$ & $\begin{array}{r}.052 \\
7.8\end{array}$ & 40 \\
\hline $\begin{array}{l}\text { Effect of } 1 \text { Std. Dev. of Socio-Economic } \\
\text { Status on Science Literacy }\end{array}$ & $\begin{array}{l}-1.1 \\
(2.5)\end{array}$ & $\begin{array}{c}2.8 \\
(1.7)\end{array}$ & $\begin{array}{l}29.2 \\
(7.3)\end{array}$ & $\begin{array}{r}.026 \\
7.2 \\
\end{array}$ & 40 \\
\hline \multicolumn{6}{|c|}{ Difference between Children of Native-Born Parents \& Children of Immigrants } \\
\hline Reading & $\begin{array}{r}-20+ \\
(13)\end{array}$ & & $\begin{array}{c}39.5 \\
(29.9)\end{array}$ & $\begin{array}{r}.049 \\
29\end{array}$ & 27 \\
\hline Mathematics & $\begin{array}{l}-28^{*} \\
(14)\end{array}$ & & $\begin{array}{l}39.0 \\
(29.9)\end{array}$ & $\begin{array}{r}.120 \\
28\end{array}$ & 23 \\
\hline Science & $\begin{array}{l}-25^{*} \\
(15)\end{array}$ & & $\begin{array}{c}47.9 \\
(32.9)\end{array}$ & $\begin{array}{r}.071 \\
32\end{array}$ & 25 \\
\hline \multicolumn{6}{|c|}{ Difference between Children of Native-Born Parents \& Foreign-born Children } \\
\hline Reading & $\begin{array}{l}-20 \\
(16)\end{array}$ & & $\begin{array}{c}53.5 \\
(38.8)\end{array}$ & $\begin{array}{l}.020 \\
11.0 \\
\end{array}$ & 30 \\
\hline Mathematics & $\begin{array}{l}-27+ \\
(.17)\end{array}$ & & $\begin{array}{c}57.9 \\
(38.8)\end{array}$ & $\begin{array}{r}.056 \\
38\end{array}$ & 26 \\
\hline Science & $\begin{array}{l}-32^{*} \\
(17)\end{array}$ & & $\begin{array}{c}56.5 \\
(42.2)\end{array}$ & $\begin{array}{r}.086 \\
40\end{array}$ & 29 \\
\hline
\end{tabular}

Source: U.S. families in the top quartile on the wealth index are on average 2.4 standard deviations above the mean for the bottom quartile. U.S. families in the top quartile on the International Socio-economic Index are 2.6 standard deviations above the mean for the bottom quartile. PISA data from OECD, Literacy Skills for the World of Tomorrow: Further Results from PISA 2000, p. 334-341, 351-352. Differentials between the children of native-born parents and the offspring of immigrants could not be calculated for many countries because there are so few immigrants. Small sample sizes mean our estimates of differentials for some countries are measured with considerable error reducing the share of variance explained. 
The bottom panel of Table 2 presents regressions predicting the test score gap between the children of native-born parents and immigrant children. These gaps could not be calculated for countries with very low rates of immigration, so we have fewer observations to include in the analysis. GDP per capita was never statistically significant when included, so we present results for a simple regression where the CBEEES dummy predicts the test score gaps. Here again a negative coefficient on the CBEEES variable implies that gaps between children of native born citizens and immigrant children are smaller when a nation has a CBEEES. All six coefficients are negative and three are significantly negative at the five percent level on a one-tail test. Two others are significant at the 10 percent level on a one-tail test. The magnitude (between 20 and 32 points) of the CBEEES coefficients predicting the gap is roughly equal to the Table 1 estimates of CBEEES impacts on the children of native-born parents. This implies that CBEEES are predicted to raise the PISA achievement scores of immigrant children by roughly twice as much as they raise scores of students with native-born parents. ${ }^{5}$

In summary, the predictions of the opponents of curriculum-based external exit exams are decisively rejected by our analysis of international data. The predictions of advocates are supported. CBEEES increase average achievement levels and tend to reduce achievement differentials between high SES and low SES students. Years spent in school are unaffected.

What do these positive findings regarding the effects of curriculum-based external exit exams in other countries suggest about the likely effects of student accountability in the United States? Only two states-New York and North Carolina-actually have a CBEEES and they became compulsory and reached universality only during the 1990s. The most popular student stakes policies in the United States-minimum competency exams and higher course graduation requirements-are very different from CBEEES. The rest of the paper provides an analysis of the effects of these policies on students who were in high school between 1988 and 1992. In section 3 we describe these policies. Section 4 uses NELS-88 data to evaluate their impacts on learning, high school completion, college attendance and labor market outcomes. 


\section{Policies For Raising Student Achievement And Improving Labor Market Success}

In the remainder of the paper we turn our attention to efforts to reform U.S. secondary schools. We compare the effectiveness of three types of educational initiatives intended to raise academic achievement and help graduates get better jobs: $(A)$ more spending to reduce class size and improve teacher quality, $(B)$ higher course graduation requirements and $(C)$ graduation exams.

States have introduced different packages of High school graduation standards. This cross state variation in graduation standards creates an opportunity to assess their impacts on student achievement and labor market success after high school. How do the impacts of these standards oriented initiatives compare with traditional policy recommendations like smaller class sizes and higher teacher salaries.

A. Smaller Class Sizes and Higher Salaries to Attract Better Teachers: There is an extensive literature on the effects of class size and teacher salaries on student learning. It has been recently reviewed by Kruger (2000), Hanushek (1997), Hedges, Laine and Greenwald (1994), Ballou and Podgursky (1999), and Ferguson (1995) so another review is not necessary here.

These policies are costly, however and there is controversy about their cost effectiveness, so state policy makers have also looked for less expensive ways of increasing student achievement. Policy makers believed that learning could be increased by getting teachers to set higher standards and by inducing students to study more diligently. Consequently, many of the education reforms introduced during the 1980s and 1990s have focused on increasing the academic focus of schools, raising the standards and expectations of teachers and inducing students to study harder. Four different policy instruments will be examined.

\section{B. State Set Minimums for the Number of Courses Required to Obtain a High}

School Diploma: The National Commission on Excellence in Education recommended in 1983 that all high school students take at least three credits (full year courses with 120 to 150 hours 
of instruction) each in mathematics, science and social studies and four credits of English. This recommendation represented a major departure from customary course taking patterns at that time. Only 14 percent of 1982 high school graduates had completed the package recommended by the Commission. No state made it a requirement.

Responding to the Commission, many states increased the number of mathematics, science and social studies courses required to graduate. Seventeen states now require students to take the thirteen core academic courses recommended by the Commission. The increase in the payoff to college during the 1980s and toughened graduation requirements appear to be having the desired effect (Bishop and Mane 2005). Low-level math courses are losing popularity and credits earned in algebra, geometry and higher-level math courses have increased 57 percent. The number of science courses taken has increased 42 percent. Fiftyfive percent of the Class of 1998 completed the 13 credit academic program recommended by the National Commission. The total number of full-year courses completed during high school has risen from 21.6 in 1982 to 25.9 for the Class of 2000 (NCES 2004).

There is, however, a potential down side to increased graduation requirements. High school graduation rates may decline. Put yourself in the shoes of a student who has failed a few courses and has therefore accumulated only 8 Carnegie units by the end of their second year in high school. In states that require only 16 Carnegie units to graduate (as Illinois does), getting a high school diploma still looks feasible. If, by contrast, the state requires 23 Carnegie units to graduate (as Louisiana and District of Columbia did in 1992), getting a diploma starts looking very difficult. Economic theory predicts that increases in the total number of courses required to graduate will induce some students to give up on getting a regular high school diploma and drop out of high school. ${ }^{6}$ Alternatively students may respond by pursuing a Graduate Equivalency Diplomas (GED) instead. Tests of these predictions carried out by Dean Lillard and Phillip DeCicca (2001), Bishop, Mane and Moriarty (2000) and by Bishop, Mane, Bishop and Moriarty (2001) have found that states with a higher than average total number of 
courses required for graduation do indeed have higher dropout rates, lower high school enrollment and graduation rates and higher numbers of GEDs awarded when other characteristics of the state are controlled. ${ }^{7}$

In 1980 forty-three states required fewer than 20 Carnegie units to graduate. Now, entering students face a 24 course minimum in five states, a 22 or 23 course minimum in thirteen states, a 21 course minimum in nine states and a 20 course minimum in another eight states.

Increases in required academic courses often precipitated these increases in total number of courses required to graduate. However, a different path could have been chosen. The total number of Carnegie units required to graduate could have been held fixed and the number of required electives reduced as academic requirements were increased. Would this have avoided stimulating an increase in dropout rates? Possibly, but, it is also possible that required academic courses are a bigger barrier to graduation than required electives. At risk students may find compulsory academic courses more difficult than the electives they would otherwise choose. Insufficient enrollment can result in the cancellation of an elective course, so their teachers may be under greater pressure to be entertaining and pass all students. On the other hand, almost all students have the option of choosing lower track academic classes where regular attendance and civility is all that is required to pass. These classes are often less demanding than the heterogeneously grouped elective classes. The class cutting and poor study habits that are the primary cause of failing grades generate problems in non-academic courses as well as academic courses. We predict, therefore, that dropout rates and graduation rates will respond to the total number of course required, not to how they are distributed between electives and academic courses. This, however, is an empirical question that will be tested below by including both $(B-1)$ the number of required academic courses and $(B-2)$ the total number of courses required to graduate in our models predicting educational outcomes.

C-1. Minimum Competency Exam Graduation Requirements: In 1996, seventeen states were awarding high school diplomas only to students who had passed a minimum 
competency exam. MCE graduation requirements were often established in response to a popular perception that the state's K-12 education system had failed. Generally speaking it has been southern states and states with large urban populations that have established MCEs. In 1992 about 40 percent of the nation's public school students lived in states that imposed a MCE graduation requirement at public high schools.

MCEs raise standards, but not for everyone. ${ }^{8}$ The standards set by the teachers of honors classes and advanced college prep classes are not changed by an MCE. Students in these classes pass the MCE on the first try without special preparation. Typically high school transcripts report only who has passed the MCE, not how far above the passing standard the student scored. The higher standards are experienced by the students who are in the school's least challenging courses. Since the challenge level of courses is positively correlated with SES, we expect MCEs to have bigger effects on low SES students than on high SES students.

School administrators will not want to be embarrassed by high failure rates, so they are likely to focus additional energy and resources on raising standards in the early grades and improving the instruction received by struggling students. In most states science, history and civics/government are not covered by the MCE, so their impact on achievement in these subjects is indirect. Presumably they raise achievement in reading, writing and mathematics and this then helps students do better in history and science classes and on tests covering these subjects.

MCEs typically set a pretty low minimum standard. In 1996 only 4 of the 17 states with MCEs targeted their graduation exams at a $10^{\text {th }}$ grade proficiency level or higher. Failure rates for students taking the test for the first time varied a great deal: from a high of $46 \%$ in Texas, $34 \%$ in Virginia, $30 \%$ in Tennessee and $27 \%$ in New Jersey to a low of $7 \%$ for Mississippi. However, since students can take the tests multiple times, eventual pass rates for the Class of 1995 were much higher: 98\% in Louisiana, Maryland, New York, North Carolina and Ohio; 96 \% in Nevada and New Jersey, $91 \%$ in Texas and $83 \%$ in Georgia. ${ }^{9}$ Since the tests are designed to determine who falls below a pretty low standard, they typically do not assess material that college bound 
students study in $10^{\text {th }}$ and $11^{\text {th }}$ grade (e.g. Algebra II and geometry proofs). As a result, MCEs should not be expected to influence learning during high school of students who did well in the first eight years of school.

\section{C-2: Voluntary End-of-Course Examinations-New York State Regents}

Examinations in the Early 1990s: End-of-Course Exams (EOCEs) are different from MCEs in that they typically assess more difficult material and are taken by students nearing the end of a specific course or sequence of courses-e.g. Biology, French, American History or Calculus. ${ }^{10}$ Teachers are inevitably viewed as responsible, at least in part, for how well their class does on the exam. EOCEs signal the student's achievement level in the subject, not just whether the student exceeds or falls below a specific cut point that all high school graduates are required to surpass. All students in the class, not just those at the bottom of the class, have an incentive to study hard to do well on the exam so an EOCE is more likely to improve classroom culture than a MCE. ${ }^{11}$ The stakes tend to be different, as well. For voluntary EOCEs, the stakes are typically getting an A rather than a B in a course or getting college credit for a high school course. For MCEs, the stakes are getting a high school diploma. To summarize, compared to MCEs, voluntary EOCEs have lower stakes but set higher standards and apply them pretty much equally to all students in a particular class, though often not in all classes or for all students in a school.

Regents Courses and Exams: Begun in the 1860s, New York State's curriculum-based Regents Examination System is the oldest American example of end-of-course examinations. Sherman Tinkelman, Assistant Commissioner for Examinations and Scholarships described the system in a 1966 report:

The Regents examinations are closely related to the curriculum in New York State. "They are, as you can see, inseparably intertwined..... These instruments presuppose and define standards.... They are a strong supervisory and instructional tool--and deliberately so. They are effective in stimulating good teaching and good learning practices." ${ }^{2}$ 
They are taken throughout one's high school career. In 1990 a college bound student taking a full schedule of Regents courses would typically take Regents exams in mathematics and earth science at the end of 9th grade; mathematics, biology and global studies exams at the end of 10th grade; mathematics, chemistry, American history, English and foreign language exams at the end of 11th grade and a physics exam at the end of 12th grade. To accommodate summer school students and courses ending in January, the exams are given three times a year.

These external exams have substantial effects on teachers. They often participate in the grading of Regents exams written by students in their school, so they can see the kinds of mistakes students are making and use that information to improve their coverage of the material the following year. Essays are graded by more than one teacher. The exams also provide a benchmark against which the teacher, her departmental colleagues and administrators may judge teaching effectiveness. Publication of school level results puts administrators under pressure to hire teachers who have deep knowledge of their subject and to introduce whole school reform programs that upgrade instruction in the early grades.

For students the stakes attached to Regents exams were pretty low. Each district decides whether Regents exam grades is to be a part of the course grade and how much weight to assign to them. While almost all districts counted Regents exam results as a final exam grade, it is averaged with quarterly grades so Regents exam scores seldom account for more than one-fifth of the student's final grade in a course. Eligibility for a "Regents" as opposed to a local diploma depended on passing the Regents exams but the benefits of getting a "Regents" diploma were small. While Regents exam grades appeared on high school transcripts, college admissions decisions depended primarily on grades and SAT scores, not Regents exam scores or Regents diplomas. ${ }^{13}$ Many students saw an advantage in taking easier "local" classes to enhance their GPAs.

Regents exams raise standards through a variety of mechanisms. First, in the classes in which they are used, they push up teaching standards and help motivate students to study and to 
cooperate with each other. Students are no longer competing for a limited number of As and Bs. Now it is possible for everyone in the class to be recognized for excellence in the subject. Secondly, Regents exam created a signal of competence that some colleges used in making admissions and placement decisions and this increased the rewards for learning and makes them more visible and immediate. Thirdly, the share of students taking the externally examined courses and the results of those exams affect the community's perception of the performance of the school district's teachers and administrators. Property values respond to these perceptions, so school boards have an incentive to push for better teaching.

The power of these incentives depends, of course, on the share of students taking externally examined courses. During the 1980 s and early 1990 s many students were not taking Regents courses and exams. In 1992 the most popular exam, Course I Mathematics, was taken by 62 percent of students, the Global Studies exam was taken by 57 percent of students and the English and Biology exams were taken by 50 percent of students. Only 38 percent of graduates earned Regent's diplomas signifying completion of a sequence of Regents courses in 1992/3. ${ }^{14}$ As a result, the Regents exam system in place in 1992 did not meet the universality requirement necessary to be classified as a CBEEES. New York State dealt with this problem by creating and expanding a system of Regents Competency Tests (RCTs) in reading, writing, math, science, global studies and U.S. history that set a minimum standard for those not taking Regents courses.

But, did increased academic course graduation requirements, minimum competency exams and voluntary end-of-course exams cause students to learn more mathematics and science and to become better readers ${ }^{15}$ Are they more likely to go to and complete college? Did they get better jobs? Since students from low SES backgrounds typically take fewer academic courses during high school, it is reasonable to hypothesize that MCE and increased course graduation requirements will have bigger effects on disadvantaged students than on high SES students. Is this hypothesis correct? These questions are addressed in the next section. 


\section{American Evidence on the Effects of Tougher Graduation Requirements: An Analysis of NELS-88 data.}

States have introduced different packages of high school graduation standards. This cross state variation in graduation standards creates an opportunity to assess their impacts on student achievement and labor market success after high school. How do the impacts of these standards oriented initiatives compare with traditional policy recommendations like smaller class sizes and higher teacher salaries?

\subsection{Data}

Our study makes use of micro data from the National Educational Longitudinal Study (NELS-88), a longitudinal data set that followed a nationally representative sample of 8th graders in 1988 through the year 1992. In addition, two post-high school follow-ups were conducted in 1994 (two years after scheduled graduation) and in 2000 (eight years after graduation). Information used in this paper comes from the student, school and family questionnaires. We studied the full sample of NELS-88 high school graduates, which comprises both graduates and drop-outs and also students from public and private high schools.

We used the restricted data set that identifies the state in which the student's high school was located. This allows us to merge information on state policies and characteristics into the data set. Four policy variables were defined characterizing graduation requirements.

The first variable measures the state government defined minimum number of academic courses (English, math, science and social studies) required to get a regular high school diploma. The second variable is the total number of credits the state required to get a high school diploma ${ }^{16}$. We include separate measures of academic and total course requirements because they correlate only .22 with each other and are likely to have different effects on learning, dropout rates and post high school outcomes.

The third variable takes on a value of 1 for states with minimum competency exam graduation requirements in 1992 (Alabama, Florida, Georgia, Hawaii, Louisiana, Maryland, 
Mississippi, Nevada, New Mexico, New Jersey, North Carolina, South Carolina, Tennessee, and Texas) and zero elsewhere ${ }^{17}$. Thirty-two percent of our sample lived in states that mandate the MCE and set the graduation standard on the exam. Finally we capture the unique effect of New York's package of graduation requirements (including voluntary Regents exams) by defining a variable that has a value of 1 if the student's high school was in New York State and 0 elsewhere. The final two policy variables are teacher salary level (using the salary paid to a first year full-time teachers in thousands of dollars) and the pupil-teacher ratio at the school ${ }^{1}$.

Since the outcomes studied are primarily determined by the student's background and environment, we control for as many characteristics of the community and the student as possible in order to increase efficiency and reduce omitted variable bias. Our estimations include controls for grade point average in $8^{\text {th }}$ grade, an average of $8^{\text {th }}$ grade test scores in English, mathematics, science and social studies, family socio-economic status and other characteristics of the student in $8^{\text {th }}$ grade. These included whether the student took remedial courses in $8^{\text {th }}$ grade or earlier, whether she has taken advanced courses, has a computer at home, TV and homework hours, reading for pleasure, an indicator for being handicapped, socioeconomic status of the student's family, logarithm of the number of books in the home, parent involvement index, family size, marital and parental status in $8^{\text {th }}$ grade, locus of control index, self esteem index and hours working for pay during $8^{\text {th }}$ grade (and it's square), an index for smoking in $8^{\text {th }}$ grade, dummies for race, ethnicity and religion and rural, suburban and urban residence and ten indicators describing the character and quality of the high school. From the principal's questionnaire we took the following indicators of quality of the student's secondary school: average teacher salary, the pupil-teacher ratio, percent free lunch, percent students that were white, school is a vocational high school, percentage of the school's full-time faculty who are vocational educators and average enrollment per high school grade (and its square). Two other measures of the quality of the school attended in $10^{\text {th }}$ grade-the average socio-economic

\footnotetext{
${ }^{1}$ Both variables come directly from the High School principal questionnaire.
} 
status and $8^{\text {th }}$ grade test scores of students at the school—were calculated by averaging student responses for each high school in the NELS:88 data base.

Controls for characteristics of the regional labor market (SMSA or state) included the unemployment rate, mean weekly wage in retailing and manufacturing, ratio of the high school graduate earnings to the high school dropout earnings in 1989, ratio of college graduate earnings to high school graduate earnings in 1989 , ratio of tuition at four year public colleges to the weekly earnings in retailing and dummies for 4 Census regions.

We are aware that the controls for student, school and labor market characteristics may not be sufficient to avoid omitted variable bias. States with high course graduation requirements or with minimum competency exams may be different along unmeasured dimensions that have direct effects on graduation rates, college attendance and wage levels. A positive selection bias is unlikely, however, because most states appear to have adopted MCEs and higher course graduation requirements as a response to a perception that the state's schools were failing to teach basic skills. By 1992 MCEs had been adopted by every southern state except Arkansas and Oklahoma. With the exception of New Mexico, none of the Mountain, Plains or Midwestern states had established a MCE prior to 1992 (US Department of Education, 1993). All our estimates report Huber-White robust standard errors that account for the clustering of students within schools and deals with the problem of the correlation of errors generated by the clusterbased sampling frame.

\subsection{Effects Of Graduation Requirements On Dropout And Graduation Rates}

Conventional wisdom predicts that higher graduation standards will increase dropout rates, postpone the graduation of some and prevent the graduation of others and that these effects will be particularly severe for low SES students (Lillard and DeCicca, 2001). More students, it is predicted, will also be induced to get a Graduate Equivalency Diploma instead and suffer an income decline as a result (Kang 1985, Costrell 1994). The prediction of economic theory is unambiguous, however, only when the rewards for getting a diploma and for effective 
teaching are unaffected by establishing higher standards. Since MCEs can improve learning and the information content of the diploma signal, the payoff to getting a diploma and to academic achievement may increase. The publicity that inevitably attends the publication of school results on tests will make teachers and administrators more accountable for the achievement of at-risk students. If the returns to greater student effort and to increased focus on teaching at-risk students induced by the higher standards do not diminish too rapidly, learning might improve enough to prevent a decline in graduation rates where MCEs have been established.

Nevertheless, the policy debate is dominated by concerns that higher standards will increase dropout rates, delay some graduations and prevent others and induce still others to get GEDs, so these are the hypotheses that will be tested.

Logistic models were estimated predicting whether the student dropout at any time during high school, whether the student gets her diploma late (in June 1992 when graduation is scheduled) and whether the student fails to get either a GED or a high school diploma by February of 1994 and also by June 2000. The estimated model was:

$$
\begin{aligned}
\mathrm{Y}_{\mathrm{i}}= & \alpha_{\mathrm{i}}+\beta_{1} \mathrm{X}_{\mathrm{i}}+\beta_{2} \mathrm{SES}_{\mathrm{i}}+\beta_{3} \mathrm{MCE}_{\mathrm{i}}+\beta_{4} \mathrm{ACAD}_{\mathrm{i}}+\beta_{5} \mathrm{TOTAL}_{\mathrm{i}}+\beta_{6} \mathrm{NY}_{\mathrm{i}}+\beta_{7} \mathrm{TCHWAGE}_{\mathrm{i}} \\
+ & \beta_{8} \mathrm{PupT} \mathrm{P} \mathrm{ChR}+\beta_{9}(\mathrm{SES} \times \mathrm{MCE})_{\mathrm{i}}+\beta_{10}\left(\mathrm{SES} \times \mathrm{ACAD}_{\mathrm{i}}+\beta_{11}(\mathrm{SES} \times \mathrm{TOTAL})_{\mathrm{i}}\right. \\
& +\beta_{12}(\mathrm{SES} \times \mathrm{NY})_{\mathrm{i}}+\beta_{13}(\mathrm{SES} \times \mathrm{TCHWAGE})_{\mathrm{i}}+\beta_{14}(\mathrm{SES} \times \mathrm{PupTchR})_{\mathrm{i}}+\mu_{\mathrm{i}}
\end{aligned}
$$

where $Y_{i}$ is a battery of dependent variables for individual $i, X_{i}$ is a vector of control variables and MCE, ACAD, TOTAL, NY, TCHWAGE and PupTchR are the policy variables. SES is a continuous variable measuring the student's family socio-economic status. We are particularly interested in the effects of these policies on equality of opportunity, so interactions were formed between each policy indicator and the socioeconomic status of the student's parents. ${ }^{18}$ Interactions were defined by deviating SES and the continuous policy variables from zero and forming their product. This insures that the main effect coefficients on the policy variables $\left[\beta_{3}, \beta_{4}\right.$, $\left.\beta_{5}, \beta_{6}, \beta_{7}, \beta_{8}\right]$ represent both the average effect of the policy and its impact on students at the mid point of the SES distribution. We also combined interaction and main effects coefficients for each 
policy to get separate estimates of the effects of policies on low SES students and high SES students. We then conducted three hypothesis tests about the impacts of each policy on students at the mid point of the SES distribution, one standard deviation (SD) above the midpoint and one SD below the mid point. These tests will allow us to comment on whether a policy helps one group more than another.

\section{Dropout Rates and Completion of High School}

Results are presented in Table $3 .^{2}$ Students living in MCE states were NOT more likely to drop out and NOT more likely to fail to get a diploma or a GED by 1994 or by 2000 . SES interactions were not statistically significant for these completion outcomes. Students living in MCE states were, however, more likely to experience delays in getting a regular diploma and also more likely to get a GED rather than the standard diploma. Contrary to our hypothesis, these two effects became larger as the student's SES increased. Indeed, effects were so small for low SES students that we were not able to reject the hypothesis that MCEs had no effect on GED and delayed graduations of low SES students.

Students living in New York State were significantly more likely to dropout, more likely to take extra time to get the diploma and more likely to get a GED rather than a regular high school diploma by year 2000. However, they were not significantly less likely to complete high school by 1994 or 2000 (e.g. to get either a diploma or a GED). None of the SES interactions were significant.

\footnotetext{
${ }^{2}$ The approximate effect of $X_{i}$ (at the mean of the dependent variable) on the probability of the event considered can be obtained by multiplying $\beta_{i}$ times $P(1-P)$.
} 
Table 3

Effects on Dropping Out and Getting the Diploma or GED

\begin{tabular}{|c|c|c|c|c|c|}
\hline & $\begin{array}{l}\text { Ever drop } \\
\text { out of High } \\
\text { School }\end{array}$ & $\begin{array}{l}\text { Diploma } \\
\text { obtained } \\
\text { late }\end{array}$ & $\begin{array}{c}\text { No HS } \\
\text { Diploma or } \\
\text { GED by } 1994\end{array}$ & $\begin{array}{c}\text { No HS } \\
\text { Diploma or } \\
\text { GED by } 2000\end{array}$ & $\begin{array}{l}\text { Obtained a } \\
\text { GED by } 2000\end{array}$ \\
\hline $\begin{array}{l}\text { Mean } \\
\text { Standard deviation }\end{array}$ & $\begin{array}{l}.121 \\
(.326)\end{array}$ & $\begin{array}{r}.082 \\
(.274)\end{array}$ & $\begin{array}{r}.081 \\
(.273)\end{array}$ & $\begin{array}{r}.050 \\
(.219)\end{array}$ & $\begin{array}{r}.064 \\
(.245)\end{array}$ \\
\hline Socio-Economic Status & $\begin{array}{r}-.571^{* * *} \\
(.066)\end{array}$ & $\begin{array}{r}-.492^{* * *} \\
(.091)\end{array}$ & $\begin{array}{r}-.657^{* * *} \\
(.094)\end{array}$ & $\begin{array}{r}-.647^{* * *} \\
(.158)\end{array}$ & $\begin{array}{r}-.407^{* * *} \\
(.109)\end{array}$ \\
\hline State Minimum Competency Exam & $\begin{array}{r}.070 \\
(.113)\end{array}$ & $\begin{array}{r}.446^{* * *} \\
(.154)\end{array}$ & $\begin{array}{r}.192 \\
(.159)\end{array}$ & $\begin{array}{l}-.255 \\
(.250)\end{array}$ & $\begin{array}{l}.385^{* *} \\
(.194)\end{array}$ \\
\hline State MCE*SES & $\begin{array}{r}.059 \\
(.104)\end{array}$ & $\begin{array}{l}.311^{* *} \\
(.145)\end{array}$ & $\begin{array}{r}-.021 \\
(.149)\end{array}$ & $\begin{array}{r}-.346 \\
(.246)\end{array}$ & $\begin{array}{l}.260+ \\
(.165)\end{array}$ \\
\hline New York & $\begin{array}{l}.421^{*} \\
(.235)\end{array}$ & $\begin{array}{r}1.18^{* * *} \\
(.247)\end{array}$ & $\begin{array}{l}.181 \\
(.324)\end{array}$ & $\begin{array}{r}-.022 \\
(.480)\end{array}$ & $\begin{array}{r}.859^{* * *} \\
(.296)\end{array}$ \\
\hline New York*SES & $\begin{array}{r}-.134 \\
(.205) \\
\end{array}$ & $\begin{array}{r}.284 \\
(.216) \\
\end{array}$ & $\begin{array}{r}-.235 \\
(.310) \\
\end{array}$ & $\begin{array}{r}-.276 \\
(.489) \\
\end{array}$ & $\begin{array}{r}-.024 \\
(.255) \\
\end{array}$ \\
\hline Academic Courses & $\begin{array}{r}.024 \\
(.030)\end{array}$ & $\begin{array}{r}.015 \\
(.040)\end{array}$ & $\begin{array}{l}.066+ \\
(.042)\end{array}$ & $\begin{array}{r}.036 \\
(.064)\end{array}$ & $\begin{array}{r}.011 \\
(.054)\end{array}$ \\
\hline Academic Courses*SES & $\begin{array}{l}.068^{* *} \\
(.030)\end{array}$ & $\begin{aligned}-.014 \\
(.035)\end{aligned}$ & $\begin{array}{l}.066+ \\
(.042)\end{array}$ & $\begin{array}{r}.049 \\
(.069)\end{array}$ & $\begin{array}{r}.019 \\
(.044)\end{array}$ \\
\hline State Minimum Credits to Graduate & $\begin{array}{r}.020 \\
(.016)\end{array}$ & $\begin{array}{r}.012 \\
(.020)\end{array}$ & $\begin{array}{r}-.033+ \\
(.021)\end{array}$ & $\begin{array}{r}.004 \\
(.036)\end{array}$ & $\begin{array}{r}.016 \\
(.026)\end{array}$ \\
\hline State Minimum*SES & $\begin{array}{r}-.018 \\
(.019)\end{array}$ & $\begin{array}{r}-.046^{* *} \\
(.023)\end{array}$ & $\begin{array}{r}-.039+ \\
(.026)\end{array}$ & $\begin{array}{r}-.001 \\
(.044)\end{array}$ & $\begin{array}{l}-.046^{*} \\
(.028)\end{array}$ \\
\hline Teacher salary & $\begin{array}{l}-. .001 \\
(.014) \\
\end{array}$ & $\begin{array}{r}-.024 \\
(.018) \\
\end{array}$ & $\begin{array}{r}-.007 \\
(.019) \\
\end{array}$ & $\begin{array}{r}-.007 \\
(.030) \\
\end{array}$ & $\begin{array}{l}-.040^{*} \\
(.022) \\
\end{array}$ \\
\hline Teacher salary*SES & $\begin{array}{r}.019 \\
(.014)\end{array}$ & $\begin{array}{r}-.015 \\
(.016)\end{array}$ & $\begin{array}{r}.024 \\
(.020)\end{array}$ & $\begin{array}{r}-.017 \\
(.031)\end{array}$ & $\begin{array}{r}-.010 \\
(.022)\end{array}$ \\
\hline Pupil teacher ratio & $\begin{array}{r}-.010 \\
(.014)\end{array}$ & $\begin{array}{r}-.028^{* *} \\
(.014)\end{array}$ & $\begin{array}{r}-.003 \\
(.017)\end{array}$ & $\begin{array}{r}.008 \\
(.026)\end{array}$ & $\begin{array}{r}.006 \\
(.017)\end{array}$ \\
\hline Pupil teacher ratio*SES & $\begin{array}{r}.004 \\
(.011)\end{array}$ & $\begin{array}{r}.013 \\
(.015)\end{array}$ & $\begin{array}{r}.011 \\
(.016)\end{array}$ & $\begin{array}{r}.004 \\
(.027)\end{array}$ & $\begin{array}{r}.022 \\
(.016)\end{array}$ \\
\hline Number of observations & 15867 & 10590 & 11922 & 9873 & 9873 \\
\hline Pseudo $\mathbf{R}^{2}$ & .256 & .169 & .292 & .350 & .170 \\
\hline
\end{tabular}

Source: Authors' analysis of National Education Longitudinal Study of 88 data. Note: Estimations using OLS. Numbers in parenthesis below the coefficient are Huber-White standard errors that correct for clustering by school. Sample includes drop outs and high school graduates from private schools. Control variables: The MCE variable is a 1 for AL, FL, GA, HI, LA, MD, MS, NV, NM, NJ, NC, SC, TN \& TX. Models also contain a full set of student background variables measured in the 8th grade: family SES, books in the home, single parent, parents divorced, \# of siblings, ethnicity, religion, gender, handicapping condition, test scores, GPA in 8th grade, hours watching TV, hours doing homework, Read for fun index, smoking, dummy for in advanced courses, dummy for in remedial courses, dummies for central city and rural, locus of control index, self esteem index and hours working for pay (plus it's square). The following characteristics of the school the student attended during 10th grade were also controlled: Catholic school, secular private school, private school controlled by a church other than the Catholic church, percent student body white, percent free lunch, mean 8th grade test score, mean family SES, enrolment per grade (plus it's square) and the share of vocational education teachers on the total number of full-time teachers. Apart from dummies for 4 Census regions, the following characteristics of the state were controlled for in the short term results (using values for 1992): drop out unemployment rate, weekly wages for drop outs, ratio of drop out earnings to high school graduate earnings, ratio of college graduate earnings to high school graduate earnings, ratio of tuition at four year public colleges to the weekly earnings in retailing. In the medium term models the state controls were: mean unemployment rate, mean weekly wages and mean weekly wages in manufacturing. ${ }^{*}$ is Statistically significant at 10 percent level on a two tail test; ** 5 percent level; ${ }^{* * *} 1$ percent level. 
Students living in states with higher elective and non-academic course graduation requirements were not more likely to drop out of high school. On the other hand, low SES students (but not middle and high SES students) were significantly more likely to get their diploma late and to get a GED. We found some weak support for the hypothesis that academic course graduation requirements have bigger effects on dropout and non-completion rates than increased elective requirements. Academic course requirements had positive coefficients in all five models and the effect was significant for "No diploma or GED by 1994" and significant for the dropout rates of high SES students.

The school resources variables--teacher salaries and pupil teacher ratios--had no effect on dropout rates or overall completion rates. Teacher salaries were, however, significantly related to lower probabilities of getting a GED diploma and for high SES students to lower probabilities of delays in getting a diploma.

\subsection{Learning and Effort during high school}

Table 4 presents models in which we predict test score gains between $8^{\text {th }}$ and $12^{\text {th }}$ grade, hours of homework per week and self perceived working hard. The number of study halls in a students schedule is the primary determinant of time spent doing homework at school. Time spent doing homework at home is probably a better measure of teacher demands and student effort than homework done at school. Students who dropped out of high school were given the tests along with those who remained in school so the reduced learning that results from some students dropping out of school is taken into account. The control variables used here are with one exception the same as those used in predicting dropping out. ${ }^{19}$ In order to prevent the error in measuring true $8^{\text {th }}$ grade achievement from biasing the results, the lagged value of the composite test did not appear on the right hand side of the regression predicting the gain on the composite from $8^{\text {th }}$ to $12^{\text {th }}$ grade. 
Table 4

Effects on Test Scores Gains During High School, Homework and Effort

\begin{tabular}{|c|c|c|c|c|c|}
\hline & $\begin{array}{l}\text { Total Test } \\
\text { Score } \\
\text { gains }\end{array}$ & $\begin{array}{c}\text { Homework } \\
\text { (hours per } \\
\text { week in } \\
\text { school) }\end{array}$ & $\begin{array}{c}\text { Homework } \\
\text { (hours per } \\
\text { week at } \\
\text { home) }\end{array}$ & $\begin{array}{c}\text { Total } \\
\text { hours } \\
\text { homework } \\
\text { (per week) }\end{array}$ & $\begin{array}{c}\text { Self } \\
\text { perception } \\
\text { of working } \\
\text { hard } \\
\end{array}$ \\
\hline $\begin{array}{l}\text { Mean } \\
\text { Standard deviation }\end{array}$ & $\begin{array}{l}7.86 \\
(4.75)\end{array}$ & $\begin{array}{l}6.44 \\
(5.66)\end{array}$ & $\begin{array}{l}6.70 \\
(5.56)\end{array}$ & $\begin{array}{l}12.98 \\
(9.46)\end{array}$ & $\begin{array}{l}3.16 \\
(.924)\end{array}$ \\
\hline Socio-Economic Status & $\begin{array}{l}.501^{* * *} \\
(.101)\end{array}$ & $\begin{array}{l}-.094 \\
(.116)\end{array}$ & $\begin{array}{l}.167+ \\
(.112)\end{array}$ & $\begin{array}{l}.098 \\
(.188)\end{array}$ & $\begin{array}{l}-.015 \\
(.019)\end{array}$ \\
\hline State Minimum Competency Exam & $\begin{array}{l}.105 \\
(.214)\end{array}$ & $\begin{array}{c}-.925^{\star * *} \\
(.224)\end{array}$ & $\begin{array}{l}-.151 \\
(.208)\end{array}$ & $\begin{array}{c}-1.07^{* * *} \\
(.354)\end{array}$ & $\begin{array}{l}.067^{* *} \\
(.034)\end{array}$ \\
\hline State MCE*SES & $\begin{array}{l}-.077 \\
(.146)\end{array}$ & $\begin{array}{l}.043 \\
(.196)\end{array}$ & $\begin{array}{l}-.258+ \\
(.176)\end{array}$ & $\begin{array}{l}-.204 \\
(.305)\end{array}$ & $\begin{array}{l}-.044 \\
(.029)\end{array}$ \\
\hline New York & $\begin{array}{l}1.09^{* * *} \\
(.381)\end{array}$ & $\begin{array}{c}-.872^{* * *} \\
(.293)\end{array}$ & $\begin{array}{l}-.745^{* *} \\
(.328)\end{array}$ & $\begin{array}{c}-1.48^{* * *} \\
(.531)\end{array}$ & $\begin{array}{l}.041 \\
(.050)\end{array}$ \\
\hline New YorkSES & $\begin{array}{l}.227 \\
(.216)\end{array}$ & $\begin{array}{l}-.005 \\
(.257)\end{array}$ & $\begin{array}{l}-.200 \\
(.263)\end{array}$ & $\begin{array}{l}-.272 \\
(.429)\end{array}$ & $\begin{array}{l}-.030 \\
(.046)\end{array}$ \\
\hline Academic Courses & $\begin{array}{l}.180^{* * *} \\
(.058)\end{array}$ & $\begin{array}{l}.150^{* \star *} \\
(.059)\end{array}$ & $\begin{array}{l}.001 \\
(.051) \\
\end{array}$ & $\begin{array}{l}.158^{*} \\
(.094) \\
\end{array}$ & $\begin{array}{l}-.015^{*} \\
(.009) \\
\end{array}$ \\
\hline Academic Courses*SES & $\begin{array}{l}.-113^{* * *} \\
(.038)\end{array}$ & $\begin{array}{l}-.048 \\
(.048)\end{array}$ & $\begin{array}{c}-.125^{* * *} \\
(.045)\end{array}$ & $\begin{array}{l}-.167^{* *} \\
(.077)\end{array}$ & $\begin{array}{l}.010 \\
(.007)\end{array}$ \\
\hline State Minimum Credits to Graduate & $\begin{array}{l}.011 \\
(.024)\end{array}$ & $\begin{array}{l}.086^{* * *} \\
(.026)\end{array}$ & $\begin{array}{l}-.014 \\
(.026)\end{array}$ & $\begin{array}{l}.065+ \\
(.042)\end{array}$ & $\begin{array}{l}.001 \\
(.004)\end{array}$ \\
\hline State Minimum*SES & $\begin{array}{l}-.002 \\
(.025)\end{array}$ & $\begin{array}{l}.031 \\
(.029)\end{array}$ & $\begin{array}{l}.049^{*} \\
(.029)\end{array}$ & $\begin{array}{l}.083^{*} \\
(.047)\end{array}$ & $\begin{array}{r}-.007+ \\
(.004)\end{array}$ \\
\hline Teacher salary & $\begin{array}{l}.018 \\
(.023)\end{array}$ & $\begin{array}{l}-.042^{*} \\
(.023)\end{array}$ & $\begin{array}{c}.012 \\
(.023)\end{array}$ & $\begin{array}{l}-.043 \\
(.040)\end{array}$ & $\begin{array}{l}-.003 \\
(.002)\end{array}$ \\
\hline Teacher salary*SES & $\begin{array}{l}-.010 \\
(.019) \\
\end{array}$ & $\begin{array}{l}-.024 \\
(.023) \\
\end{array}$ & $\begin{array}{l}.008 \\
(.023) \\
\end{array}$ & $\begin{array}{l}-.016 \\
(.038) \\
\end{array}$ & $\begin{array}{l}-.002 \\
(.004) \\
\end{array}$ \\
\hline Pupil teacher ratio & $\begin{array}{c}-.059^{* * *} \\
(.018) \\
\end{array}$ & $\begin{array}{l}-.009 \\
(.021) \\
\end{array}$ & $\begin{array}{l}-.021 \\
(.019) \\
\end{array}$ & $\begin{array}{l}-.029 \\
(.034) \\
\end{array}$ & $\begin{array}{c}.001 \\
(.003) \\
\end{array}$ \\
\hline Pupil teacher ratio*SES & $\begin{array}{l}-.022 \\
(.015)\end{array}$ & $\begin{array}{c}.022 \\
(.019)\end{array}$ & $\begin{array}{c}-.064^{* * *} \\
(.018)\end{array}$ & $\begin{array}{l}-.040 \\
(.033)\end{array}$ & $\begin{array}{l}-.001 \\
(.003)\end{array}$ \\
\hline Number of observations & 11369 & 13078 & 13127 & 13051 & 10745 \\
\hline $\begin{array}{l}\mathrm{R}^{2} \\
\text { Root MSE }\end{array}$ & $\begin{array}{c}.102 \\
4.639 \\
\end{array}$ & $\begin{array}{c}.054 \\
5.496\end{array}$ & $\begin{array}{c}.151 \\
5.184\end{array}$ & $\begin{array}{c}.094 \\
9.029\end{array}$ & $\begin{array}{l}.074 \\
.892\end{array}$ \\
\hline
\end{tabular}

Source: Authors' analysis of National Education Longitudinal Study of 88 data. Note: Estimations using OLS. Numbers in parenthesis below the coefficient are Huber-White standard errors that correct for clustering by school. Sample includes drop outs and high school graduates from private schools. Control variables: The MCE variable is a 1 for AL, FL, GA, HI, LA, MD, MS, NV, NM, NJ, NC, SC, TN \& TX. Models also contain a full set of student background variables measured in the $8^{\text {th }}$ grade: family SES, books in the home, single parent, parents divorced, \# of siblings, ethnicity, religion, gender, handicapping condition, test scores, GPA in $8^{\text {th }}$ grade, hours watching TV, hours doing homework, Read for fun index, smoking, dummy for in advanced courses, dummy for in remedial courses, dummies for central city and rural, locus of control index, self esteem index and hours working for pay (plus it's square). The following characteristics of the school the student attended during $10^{\text {th }}$ grade were also controlled: Catholic school, secular private school, private school controlled by a church other than the Catholic church, teacher salary, percent student body white, percent free lunch, mean $8^{\text {th }}$ grade test score, mean family SES and enrollment per grade (plus it's square). Apart from dummies for 4 Census regions, the following characteristics of the state were controlled for: mean unemployment rate, mean weekly wages in retailing and manufacturing (in logs) and ratio of tuition at four year public colleges to the weekly earnings in retailing. Statistically significant at 10 percent level on a two tail test; ${ }^{* \star} 5$ percent level; ${ }^{* \star *} 1$ percent level. 
Our most important finding is that academic course requirements have significant positive effects on learning. Students in states requiring four extra academic courses to graduate learned .37 grade level equivalents more in the four core academic subjects $\left[\left(4^{*} .18\right) /\left(.25^{*} 7.86\right)\right]$ than comparable students in other states. Increased elective and non-academic course requirements, by contrast, had no effect on learning core academic subjects. MCEs also had no effect on learning. Students living in MCE states reported that they worked harder but that they did less homework in school.

Our third finding is that end-of-course exams combined with MCEs—or something else in the New York State policy mix —appears to have had large significant effects on learning during high school. The New York effect was slightly more than one-half a grade level equivalent. This occurred despite the fact that dropout rates are higher in New York than in most other states and dropouts learn considerably less than students who stay in school. NELS:88 students who had dropped out of school were tested in 1992 along with everyone else. Those who stayed in school learned enough extra to counterbalance the negative effects of New York's higher dropout rate.

Reductions in the pupil-teacher ratio are associated with a statistically significant increase in learning during high school. The regression predicts that reducing the number of pupils per teacher by four (a one standard deviation change in the variable) will increase learning over the four year period by about 12 percent of a GLE. This 3 percent increase in the rate of learning seems to be a rather modest when one considers that the policy requires a 25 percent increase in the number of teachers at the school (probably implying a 10+ percent increase in costs per student).

\subsection{College Attendance and Completion}

If tougher high school graduation requirements raise the achievement of high school graduates, as intended, they should increase the proportion of high school graduates going to college. Analyzing HSB data, Bishop and Mane (1999) found that high school graduates coming from high schools with an MCE graduation requirement [as reported by the principal] were 
significantly more likely to be in college during the four-year period immediately following high school graduation. Effects were largest for students in the middle and bottom of the test score distribution and tended to be greater in the $2^{\text {nd }}$ and $3^{\text {rd }}$ years out than in the $1^{\text {st }}, 4^{\text {th }}$ and subsequent years out. Opponents of tougher graduation requirements concede this point but argue that it may be accomplished by reducing the number of high school graduates not by increasing the numbers attending and completing college.

To avoid this problem we need to study the proportion of $8^{\text {th }}$ graders who subsequently go to college not the proportion of high school graduates who go to college. Opponents of tougher graduation requirements predict that the reductions in high school graduation rates they expect to result will then lower the proportion of $8^{\text {th }}$ graders with low GPAs who eventually attend college. Proponents of MCEs disagree. They argue that MCE tests assess very basic skills and that students who cannot, after many tries, pass such tests are not prepared for college level work. Open door institutions will admit them, but they will need extensive remedial course work and are unlikely to complete any course of study. It is better, they argue, for high schools to hold all students to higher standards and that poorly prepared students be told of their deficiencies early in high school when there is time to do something about it. The result, they argue, will be an increase in the number of high school graduates who have the skills and knowledge necessary to succeed and thrive in college. They, therefore, would predict that, even when tougher graduation requirements delay or prevent some from graduating from high school, the proportion of $8^{\text {th }}$ graders who enter college on schedule in fall 1992 will not decline and a year or so later college enrollment rates will be higher. The positive effect of higher expectations in high school on college enrollment rates is delayed because some enter college one year later due to delays in completing high school and because college dropout rates fall.

Using longitudinal data on students who were in $8^{\text {th }}$ grade in the spring of 1988 , logistic regressions were estimated predicting college enrollment in the fall of 1992 and the spring of 1994 and completion with an Associates or Bachelors degree or better by the year 2000. The 
model specifications were the same as those used in the dropout and high school completion models. ${ }^{20}$ The results are presented in table 5.

Table 5

College Attendance and Completion

\begin{tabular}{|c|c|c|c|c|}
\hline & \begin{tabular}{|c} 
Enrolled in Fall \\
1992
\end{tabular} & \begin{tabular}{|c|} 
Enrolled in Spring \\
1994
\end{tabular} & $\begin{array}{c}\text { Obtained an associate } \\
\text { or higher }\end{array}$ & $\begin{array}{c}\text { Obtained a bachelor } \\
\text { or higher }\end{array}$ \\
\hline Mean Standard deviation & $\begin{array}{l}.592 \\
(.491)\end{array}$ & $\begin{array}{l}.558 \\
(.496)\end{array}$ & $\begin{array}{l}.420 \\
(.493)\end{array}$ & $\begin{array}{l}.346 \\
(.475)\end{array}$ \\
\hline Socio-Economic Status & $\begin{array}{l}.737^{* * *} \\
(.054)\end{array}$ & $\begin{array}{l}.678^{* * *} \\
(.055)\end{array}$ & $\begin{array}{l}.648^{* * *} \\
(.056)\end{array}$ & $\begin{array}{l}.811^{* * *} \\
(.064)\end{array}$ \\
\hline $\begin{array}{l}\text { State Minimum Competency } \\
\text { Exam }\end{array}$ & $\begin{array}{l}.020 \\
(.094)\end{array}$ & $\begin{array}{l}.167^{*} \\
(.089)\end{array}$ & $\begin{array}{l}.041 \\
(.101)\end{array}$ & $\begin{array}{l}-.017 \\
(.117)\end{array}$ \\
\hline State MCE*SES & $\begin{array}{l}.014 \\
(.089)\end{array}$ & $\begin{array}{l}.209^{* *} \\
(.089)\end{array}$ & $\begin{array}{l}.131 \\
(.094)\end{array}$ & $\begin{array}{l}.093 \\
(.109)\end{array}$ \\
\hline New York & $\begin{array}{l}.051 \\
(.144)\end{array}$ & $\begin{array}{l}.082 \\
(.141)\end{array}$ & $\begin{array}{l}-.075 \\
(.159)\end{array}$ & $\begin{array}{l}-.337^{*} \\
(.195)\end{array}$ \\
\hline New York*SES & $\begin{array}{l}-.280^{* *} \\
(.132)\end{array}$ & $\begin{array}{l}-.018 \\
(.142)\end{array}$ & $\begin{array}{l}-.123 \\
(.144)\end{array}$ & $\begin{array}{l}-.160 \\
(.157)\end{array}$ \\
\hline Academic Courses & $\begin{array}{l}.032 \\
(.024) \\
\end{array}$ & $\begin{array}{l}-.015 \\
(.023) \\
\end{array}$ & $\begin{array}{l}-.019 \\
(.025) \\
\end{array}$ & $\begin{array}{l}-.026 \\
(.030)\end{array}$ \\
\hline Academic Courses*SES & $\begin{array}{l}.014 \\
(.022)\end{array}$ & $\begin{array}{l}-.046^{* *} \\
(.023)\end{array}$ & $\begin{array}{l}-.009 \\
(.023)\end{array}$ & $\begin{array}{l}-.015 \\
(.027)\end{array}$ \\
\hline $\begin{array}{l}\text { State Minimum Credits to } \\
\text { Graduate }\end{array}$ & $\begin{array}{l}-.016 \\
(.012)\end{array}$ & $\begin{array}{l}-.020^{*} \\
(.011)\end{array}$ & $\begin{array}{l}-.003 \\
(.012)\end{array}$ & $\begin{array}{l}-.001 \\
(.014)\end{array}$ \\
\hline State Minimum*SES & $\begin{array}{l}.021+ \\
(.013)\end{array}$ & $\begin{array}{l}.027^{* *} \\
(.013)\end{array}$ & $\begin{array}{c}.012 \\
(.014) \\
\end{array}$ & $\begin{array}{c}.020 \\
(.017) \\
\end{array}$ \\
\hline Teacher salary & $\begin{array}{l}.024^{* *} \\
(.010)\end{array}$ & $\begin{array}{l}.024^{\star *} \\
(.010)\end{array}$ & $\begin{array}{l}.036^{\star * *} \\
(.012)\end{array}$ & $\begin{array}{l}.037^{* \star *} \\
(.012)\end{array}$ \\
\hline Teacher salary*SES & $\begin{array}{c}-.025^{\star *} \\
(.011)\end{array}$ & $\begin{array}{l}-.002 \\
(.011)\end{array}$ & $\begin{array}{l}-.002 \\
(.013)\end{array}$ & $\begin{array}{l}-.010 \\
(.014)\end{array}$ \\
\hline Pupil teacher ratio & $\begin{array}{l}.002 \\
(.008)\end{array}$ & $\begin{array}{l}-.011 \\
(.008)\end{array}$ & $\begin{array}{c}-.022^{* \star *} \\
(.010)\end{array}$ & $\begin{array}{l}-.017^{*} \\
(.010)\end{array}$ \\
\hline Pupil teacher ratio*SES & $\begin{array}{l}.012 \\
(.009) \\
\end{array}$ & $\begin{array}{c}-.023^{* * *} \\
(.008)\end{array}$ & $\begin{array}{c}.003 \\
(.009) \\
\end{array}$ & $\begin{array}{l}.003 \\
(.011) \\
\end{array}$ \\
\hline Number of observations & 11828 & 11829 & 9902 & 9902 \\
\hline Pseudo $\mathrm{R}^{2}$ & .270 & .274 & .289 & .362 \\
\hline
\end{tabular}

Source: Authors' analysis of National Education Longitudinal Study of 88 data. Note: Estimations using OLS. Numbers in parenthesis below the coefficient are Huber-White standard errors that correct for clustering by school. Sample includes drop outs and high school graduates from private schools. Control variables: The MCE variable is a 1 for AL, FL, GA, HI, LA, MD, MS, NV, NM, NJ, NC, SC, TN \& TX. Models also contain a full set of student background variables measured in the $8^{\text {th }}$ grade: family SES, books in the home, single parent, parents divorced, \# of siblings, ethnicity, religion, gender, handicapping condition, test scores, GPA in $8^{\text {th }}$ grade, hours watching TV, hours doing homework, Read for fun index, smoking, dummy for in advanced courses, dummy for in remedial courses, dummies for central city and rural, locus of control index, self esteem index and hours working for pay (plus it's square). The following characteristics of the school the student attended during $10^{\text {th }}$ grade were also controlled: Catholic school, secular private school, private school controlled by a church other than the Catholic church, teacher salary, percent student body white, percent free lunch, mean $8^{\text {th }}$ grade test score, mean family SES and enrolment per grade (plus it's square). Apart from dummies for 4 Census regions, the following characteristics of the state were controlled for: mean unemployment rate, mean weekly wages in retailing (in log), ratio of college graduate earnings to high school graduate earnings and ratio of tuition at four year public colleges to the weekly earnings in retailing. Statistically significant at 10 percent level on a two tail test; ${ }^{* *} 5$ percent level; ${ }^{* * *} 1$ percent level. 
Academic course requirements had no significant effects on college attendance or college completion. Increases in the total number of courses required to graduate (holding academic course requirements constant) significantly lowered college attendance rates in spring of 1994. This negative effect was significantly larger for low SES students. A four credit increase in elective and non-academic course graduation requirements is predicted to reduce college enrollment of low SES students by 3.3 percentage points in fall 1992 and by 4.2 percentage points in spring 1994. These enrollment effects seem to be transitory because neither policy had significant impacts on the probability of getting college degrees by the year 2000.

MCEs had significant positive effects on college attendance, but only in the sixth year after $8^{\text {th }}$ grade not the fifth year. Students in MCE states had rates of college attendance that were about 4 percentage points higher in 1994. The positive effect was larger for students from high SES backgrounds. MCEs had no effect on 1994 college attendance rates of low SES students. Again these enrollment effects seem to be temporary because attending high school in a MCE state has no effect on the likelihood of getting college degrees. Attending school in New York had positive effects on college attendance rates of low SES students in fall 1992. Completion rates, on the other hand, are lower in New York particularly for high SES students.

Of the six policies reviewed, teacher salary had the most consistent and statistically significant impact on college attendance and completion. A 15 percent (one standard deviation) increase in teacher salary raises college attendance rates by 1.8 percentage points and college completion rates by 2.5 percentage points. The 1992 enrollment effect is 3.3 percentage points for low SES students. No other SES interactions were significant. Pupil-teacher ratio has significant effects on college completion but not on enrolment rates. A 25 percent decrease in the pupil-teacher ratio is associated with a 1.5 percentage point increase in the proportion getting a Bachelors degree and a 2 point increase in the probability of getting an associates degree or better. 


\subsection{Labor Market Outcomes}

Policy makers have justified increased graduation requirements as necessary to prepare young people to compete in the world economy. MCEs and tougher course graduation requirements are hypothesized to improve job opportunities in two ways. First, if they improve student achievement, they raise worker productivity. ${ }^{21}$ Even when this does not immediately raise workers' earnings, the effect of academic achievement on wages grows with time and eventually becomes very large. ${ }^{22}$

The second way MCEs and higher course graduation requirements could improve job opportunities is by sending a signal to employers that "ALL the graduates of this high school meet or exceed your hiring standards." The fact that they have taken a core curriculum and passed the MCE is the proof. In most communities, competencies developed in the local high school are poorly signaled to employers. The lack of signals of achievement in high school tends to make employers with the best jobs reluctant to risk hiring recent high school graduates. Indeed they often carry in their head very negative stereotypes regarding recent high school graduates. A black personnel director interviewed for a CBS special on educational reform proudly stated, "We don't hire high school graduates any more, we need skilled workers." ${ }^{23}$ They prefer, instead, to hire workers with many years of work experience because the applicant's work record serves as a signal of competence and reliability that helps them identify the most qualified.

Raising course graduation requirements and/or instituting graduation tests, therefore, are strategies some states have pursued to attract high wage employers and help recent graduates compete for good jobs. Local Chambers of Commerce have lobbied state government to set higher graduation standards. When tougher standards were instituted, one would expect local employers to be aware of the change. Diplomas now signal that the student took a core academic curriculum and met or exceeded certain minimum standards in core subjects. Because of pooling, all high school graduates should benefit. Students previously stigmatized by race or social background should benefit most of all. 
Previous studies have found that MCEs raise earnings immediately after high school. ${ }^{24}$ Have these policies indeed improved the labor market outcomes for recent high school graduates? To answer this question we estimated models predicting labor market outcomes in 1993-4 and 2000. The early indicators were total number of months worked during the 21 month period from July 1992 to March 1994, hourly wage rate (logged) and earnings in calendar year 1993. The three indicators of medium term labor market success were: annual earnings of the job occupied during the first quarter of the year 2000 , the hours worked per week in that job and the hourly wage rate of that job. Wage rates are not defined for respondents who did not report a job sometime during $1993-94$ or 2000 . The other variables treated those who reported no work during the reference period as a zero (the variable was missing if the individual reported work but did not report earnings or hours worked).

Since attending college reduces the time available for work, we included an extensive set of controls for current and past college attendance: the number of semesters of full-time college attendance during the period from fall 1992 to Spring 1994, number of semesters of part-time college attendance during that same period, the number semesters attending a two year institution full-time and the number of semesters of part-time attendance at a two year institution. We also included controls for "Attending college full time in the first quarter of 2000", "Attending college part time in the first quarter of 2000," "Ever dropped out of high school," "Obtained a GED," "graduated early" and, for late graduates, "the length of the delay in graduation." In the models predicting medium term outcomes, we included dummy variables for some college, for 'ever attended a 4 year college', for earning a vocational certificate, for an associate degree, a bachelors degree, a masters degree and graduate or professional degrees. Family structure in 2000 was controlled by four indicator variables: married male, married female, male with children and female with children.

Our analyses of the effects of graduation requirements on early labor market outcomes are presented in Table 6. Increases in the number of elective courses to graduate did not have 
positive effects on any labor market indicator; quite the reverse. Increased elective course requirements significantly lowered wage rates and earnings both in 1994 and in 2000 . The negative effects for year 2000 are larger for high SES students and essentially zero for low SES students. Academic course requirements were significantly related to higher wage rates in 1994 and 2000 and to higher earnings in 2000 . This effect did not vary significantly by SES. Being required to take extra academic courses had a significantly more positive effect on wage rates than elective course requirements. This implies that if total graduation requirements are fixed, increasing academic requirements will increase wage rates by roughly one percentage point for each one credit increase in academic course requirements. However, when an increase in academic course requirements is associated with an equal increase in total course requirements, wages and earnings remain essentially unchanged.

Minimum competency exams, by contrast, had large and significant effects on many of the labor market indicators. Those who attended high school in MCE states earned 11 percent (\$548.) more in 1993 and 4.2 percent (\$1103.) more in 2000 . Wage rates were also a significant 2.6 percent higher in 2000. SES interactions are very interesting. Consistent with our hypothesis, MCE effects were significantly more positive for low SES students in 1993. Contrary to our hypothesis, this pattern reversed six years later. In 2000, our estimates of the MCE effect are $\$ 2375$ for high SES graduates and essentially zero for low SES graduates. The confidence intervals for the coefficients characterizing the effect of attending school in New York are very wide, so nothing is statistically significant. However, for the year 2000 , the coefficients on the NY dummy are very similar to the coefficients on the MCE dummy including the positive interaction.

Pupil-teacher ratios did not have significant effects on wage rates or earnings. Teacher salary was negatively related to time spent working in both 1993 and 2000 . It was also positively related to year 2000 wage rates of middle SES and high SES students but not for low SES students. 
Table 6

Labor Market Effects

\begin{tabular}{|c|c|c|c|c|c|c|}
\hline & \multicolumn{3}{|c|}{ Short term results } & \multicolumn{3}{|c|}{ Mid term results } \\
\hline & $\begin{array}{c}\text { Employment } \\
\text { (months) }\end{array}$ & \begin{tabular}{|c|} 
Wages (log \\
hourly wage)
\end{tabular} & $\begin{array}{c}\text { Earnings } \\
\text { (yearly) }\end{array}$ & $\begin{array}{l}\text { Employment } \\
\text { (hours week) }\end{array}$ & $\begin{array}{c}\text { Wages (log } \\
\text { hourly wage) }\end{array}$ & $\begin{array}{c}\text { Earnings } \\
\text { (yearly) }\end{array}$ \\
\hline $\begin{array}{l}\text { Mean } \\
\text { Standard deviation }\end{array}$ & $\begin{array}{l}13.51 \\
(7.64)\end{array}$ & $\begin{array}{l}1.272 \\
(.563)\end{array}$ & $\begin{array}{l}5152 \\
(5453)\end{array}$ & $\begin{array}{c}36.19 \\
(16.07)\end{array}$ & $\begin{array}{c}2.53 \\
(.447)\end{array}$ & $\begin{array}{c}26137 \\
(19426)\end{array}$ \\
\hline Socio-Economic Status & $\begin{array}{l}-.437^{* * *} \\
(.163) \\
\end{array}$ & $\begin{aligned}-.018+ \\
(.011) \\
\end{aligned}$ & $\begin{array}{l}-109 \\
(116) \\
\end{array}$ & $\begin{array}{l}-.076 \\
(.303) \\
\end{array}$ & $\begin{array}{l}.011 \\
(.010)\end{array}$ & $\begin{array}{c}28 \\
(399)\end{array}$ \\
\hline State Minimum Competency Exam & $\begin{array}{l}.067 \\
(.261)\end{array}$ & $\begin{array}{l}-.002 \\
(.018)\end{array}$ & $\begin{array}{c}548^{* * *} \\
(180)\end{array}$ & $\begin{array}{l}.019 \\
(.508)\end{array}$ & $\begin{array}{l}.026^{*} \\
(.015)\end{array}$ & $\begin{array}{l}1103^{*} \\
(593)\end{array}$ \\
\hline State MCE*SES & $\begin{array}{l}-.432^{*} \\
(.261)\end{array}$ & $\begin{array}{c}.008 \\
.016)\end{array}$ & $\begin{array}{c}-404^{\star * *} \\
(164)\end{array}$ & $\begin{array}{l}.0070 \\
.510)\end{array}$ & $\begin{array}{l}.037^{* \star *} \\
(.015)\end{array}$ & $\begin{array}{c}1590^{\star * *} \\
(615)\end{array}$ \\
\hline New York & $\begin{array}{l}-.544 \\
(.440)\end{array}$ & $\begin{array}{l}-.005 \\
(.031)\end{array}$ & $\begin{array}{c}5 \\
(265) \\
\end{array}$ & $\begin{array}{l}-.935 \\
(.790)\end{array}$ & $\begin{array}{c}.036 \\
(.026)\end{array}$ & $\begin{array}{c}742 \\
(1149)\end{array}$ \\
\hline New YorkSES & $\begin{array}{l}-.085 \\
(.497)\end{array}$ & $\begin{array}{l}-.006 \\
(.032)\end{array}$ & $\begin{array}{l}-318 \\
(292)\end{array}$ & $\begin{array}{l}1.86^{* * *} \\
(.768)\end{array}$ & $\begin{array}{l}-.024 \\
(.026)\end{array}$ & $\begin{array}{c}1386 \\
(1304)\end{array}$ \\
\hline Academic Courses & $\begin{array}{c}.064 \\
(.073)\end{array}$ & $\begin{array}{l}.011^{* *} \\
(.005)\end{array}$ & $\begin{array}{c}-6 \\
(51)\end{array}$ & $\begin{array}{c}.011 \\
(.134)\end{array}$ & $\begin{array}{l}.007+ \\
(.004)\end{array}$ & $\begin{array}{l}243+ \\
(159)\end{array}$ \\
\hline Academic Courses ${ }^{\star S E S}$ & $\begin{array}{l}-.024 \\
(.066)\end{array}$ & $\begin{array}{l}-.005 \\
(.004)\end{array}$ & $\begin{array}{c}2 \\
(38)\end{array}$ & $\begin{array}{l}-.084 \\
(.123)\end{array}$ & $\begin{array}{l}.003 \\
(.004)\end{array}$ & $\begin{array}{c}16 \\
(167)\end{array}$ \\
\hline $\begin{array}{l}\text { State Minimum Credits to } \\
\text { Graduate }\end{array}$ & $\begin{array}{l}-.028 \\
(.032)\end{array}$ & $\begin{array}{l}-.006^{\star \star \star} \\
(.002)\end{array}$ & $\begin{array}{l}-44^{* *} \\
(23) \\
\end{array}$ & $\begin{array}{c}.034 \\
(.059) \\
\end{array}$ & $\begin{array}{c}-.007^{* * *} \\
(.001)\end{array}$ & $\begin{array}{l}-197^{* * *} \\
(77)\end{array}$ \\
\hline State Minimum*SES & $\begin{array}{l}-.008 \\
(.038)\end{array}$ & $\begin{array}{l}-.001 \\
(.002)\end{array}$ & $\begin{array}{c}18 \\
(26)\end{array}$ & $\begin{array}{l}.028 \\
(.072)\end{array}$ & $\begin{array}{l}-.005^{\star *} \\
(.002)\end{array}$ & $\begin{array}{c}-201^{* *} \\
(105)\end{array}$ \\
\hline Teacher salary & $\begin{array}{c}-.090^{\star \star \star} \\
(.035)\end{array}$ & $\begin{array}{l}-.002 \\
(.002)\end{array}$ & $\begin{array}{l}-14 \\
(22)\end{array}$ & $\begin{array}{l}-.105^{*} \\
(.057)\end{array}$ & $\begin{array}{l}.003^{*} \\
(.002)\end{array}$ & $\begin{array}{l}-19 \\
(70)\end{array}$ \\
\hline Teacher salary*SES & $\begin{array}{l}-.025 \\
(.033)\end{array}$ & $\begin{array}{c}.001 \\
(.002)\end{array}$ & $\begin{array}{l}36^{*} \\
(19)\end{array}$ & $\begin{array}{c}.001 \\
(.063)\end{array}$ & $\begin{array}{l}.004^{* *} \\
(.002)\end{array}$ & $\begin{array}{c}64 \\
(75) \\
\end{array}$ \\
\hline Pupil teacher ratio & $\begin{array}{l}-.015 \\
(.024)\end{array}$ & $\begin{array}{l}.002 \\
(.002)\end{array}$ & $\begin{array}{c}8 \\
(17)\end{array}$ & $\begin{array}{l}-.015 \\
(.043)\end{array}$ & $\begin{array}{l}.002 \\
(.002)\end{array}$ & $\begin{array}{c}2 \\
(56)\end{array}$ \\
\hline Pupil teacher ratio*SES & $\begin{array}{l}.038+ \\
(.024)\end{array}$ & $\begin{array}{c}.002 \\
(.002)\end{array}$ & $\begin{array}{l}34^{* *} \\
(17)\end{array}$ & $\begin{array}{l}-.066 \\
(.054)\end{array}$ & $\begin{array}{l}-.001 \\
(.002)\end{array}$ & $\begin{array}{l}-85 \\
(64)\end{array}$ \\
\hline Number of observations & 11656 & 11594 & 9885 & 9810 & 8108 & 9378 \\
\hline$R^{2}$ Root MSE & $\begin{array}{l}.147 \\
7.085\end{array}$ & $\begin{array}{l}.092 \\
.541\end{array}$ & $\begin{array}{l}.238 \\
4860\end{array}$ & $\begin{array}{c}.330 \\
13.202\end{array}$ & $\begin{array}{l}.219 \\
.3931\end{array}$ & $\begin{array}{l}.285 \\
16637\end{array}$ \\
\hline
\end{tabular}

Source: Authors' analysis of National Education Longitudinal Study of 88 data. Note: Estimations using OLS. Numbers in parenthesis below the coefficient are Huber-White standard errors that correct for clustering by school. Sample includes drop outs and high school graduates from private schools. Control variables: The MCE variable is a 1 for AL, FL, GA, HI, LA, MD, MS, NV, NM, NJ, NC, SC, TN \& TX. Models also contain a full set of student background variables measured in the $8^{\text {th }}$ grade: family SES, books in the home, single parent, parents divorced, \# of siblings, ethnicity, religion, gender, handicapping condition, test scores, GPA in $8^{\text {th }}$ grade, hours watching TV, hours doing homework, Read for fun index, smoking, dummy for in advanced courses, dummy for in remedial courses, dummies for central city and rural, locus of control index, self esteem index and hours working for pay (plus it's square). The following characteristics of the school the student attended during $10^{\text {th }}$ grade were also controlled: Catholic school, secular private school, private school controlled by a church other than the Catholic church, teacher salary, percent student body white, percent free lunch, mean $8^{\text {th }}$ grade test score, mean family SES and enrollment per grade (plus it's square). The following characteristics of the state were controlled for: mean unemployment rate, mean weekly wages in retailing and manufacturing and dummies for 4 Census regions. We also included college experience and status in 1993 and in the models predicting outcomes for the year 2000 there also were included marital status, number of dependents, higher degree obtained by 2000 , college status and date of degree. Statistically significant at 10 percent level on a two tail test; ${ }^{* *} 5$ percent level; ${ }^{* * *} 1$ percent level. 


\section{The Effects of Policy Initiatives to Increase Academic Achievement and Labor Market Outcomes: Summary and Policy Implications}

The purpose of this paper has been to measure the effects of increased academic standards on both average achievement levels and on equality of opportunity? The five policies evaluated were: (1) universal Curriculum-Based External Exit Exam Systems, (2) voluntary curriculum-based external exit exam systems with partial coverage such as New York State Regents exams in 1992, (3) state minimum competency graduation tests, (4) state defined minimums for the total number of courses students must take and pass to get a high school diploma and (5) state defined minimums for the number of academic courses necessary to get a diploma. We also measured the effects of school-to-school variations in teacher salaries and student-teacher ratios for comparison purposes. Since universal curriculum-based external exams had not been implemented in the U.S. prior to 1992, international data was analyzed to evaluate the effects of CBEEES. High school graduation standards differ a lot across states in the U.S. This allowed us to measure policy effects on student achievement and labor market success after high school by comparing states in a multiple regression framework.

In Table 7 we summarize our main findings for test scores, high school attendance and completion, college attendance and completion and success in the labor market. In the odd numbered columns we present our estimates of the mean percentage change in each of our eight outcomes that the regressions predict would be generated by introducing a discrete reform (such as an MCE or a CBEEES) or by a large (4 credit) increase in the number of courses (academic or total) required to get a regular diploma. For comparison purposes we also calculate and present the predicted effects of increasing teacher wages by 30 percent (or two standard deviations) and decreasing student teacher ratios by 40 percent (eight fewer students per teacher). 
Table 7

Effects of School Policies

(\% Effect Relative to the Mean of a Two Standard Deviation Change in Policy)

\begin{tabular}{|c|c|c|c|c|c|c|c|c|c|c|c|c|c|c|c|c|}
\hline \multirow{2}{*}{\begin{tabular}{|l|}
\multicolumn{1}{|c|}{ Outcomes $\rightarrow$} \\
Policies \\
\end{tabular}} & \multicolumn{2}{|c|}{$\begin{array}{l}\text { Average } \\
\text { Test scores } \\
\text { (\% of a GLE) }\end{array}$} & \multicolumn{2}{|c|}{$\begin{array}{l}\text { Attend High } \\
\text { School }\end{array}$} & \multicolumn{2}{|c|}{$\begin{array}{l}\text { Get GED or High } \\
\text { School Diploma }\end{array}$} & \multicolumn{2}{|c|}{$\begin{array}{l}\text { Attend College } \\
\text { or University }\end{array}$} & \multicolumn{2}{|c|}{$\begin{array}{c}\text { Get } 2 \text { or } 4 \text { Yr } \\
\text { College Diploma }\end{array}$} & \multicolumn{2}{|c|}{$\begin{array}{c}\text { Earnings } 1^{\text {st }} \mathrm{yr} \\
\text { after H.S. } \\
\text { Graduation }\end{array}$} & \multicolumn{2}{|c|}{$\begin{array}{c}\text { Earnings 8th yr. } \\
\text { after H.S. } \\
\text { Graduation }\end{array}$} & \multicolumn{2}{|c|}{$\begin{array}{c}\text { Wage Rate } 8^{\text {th }} \mathrm{yr} \text {. } \\
\text { after H.S. } \\
\text { Graduation }\end{array}$} \\
\hline & Mean & Gap & mean & GAP & mean & GAP & mean & GAP & Mean & GAP & Mean & GAP & Mean & GAP & Mean & GAP \\
\hline Universal CBEEES & $120^{* * *}$ & $-40^{\star *}$ & -3 & --- & $11^{*}$ & --- & 4 & -- & --- & ---- & --- & --- & ---- & --- & --- & --- \\
\hline $\begin{array}{l}\text { Voluntary End-of- } \\
\text { Course Exams }\end{array}$ & $55^{\star * *}$ & 18 & $-4.5^{*}$ & 2.3 & 0 & 1.6 & 4.1 & -1 & -4 & -11 & 0 & -10 & 2.8 & 8.4 & 3.6 & -3.8 \\
\hline $\begin{array}{l}\text { Minimum } \\
\text { Competency Exam }\end{array}$ & 5 & -6 & -0.7 & -1 & 0 & 2 & $8^{* *}$ & $17^{* *}$ & 2 & 12 & $11^{* * *}$ & $-13^{* * *}$ & $4.2^{*}$ & $9.7^{* * *}$ & $2.6^{*}$ & $5.9^{* * *}$ \\
\hline $\begin{array}{l}4 \text { more Academic } \\
\text { Credits Required }\end{array}$ & $37^{\star \star \star}$ & $-37^{* * *}$ & -1 & $-3^{* *}$ & -1.6 & -2.4 & -3.0 & $-15^{\star *}$ & -4 & -.3 & 0 & 0 & $3.7+$ & 0 & $2.8+$ & 1.9 \\
\hline $\begin{array}{l}4 \text { extra Total } \\
\text { Credits Required }\end{array}$ & 2 & 0 & -0.9 & 1.2 & 0.4 & -0.8 & $-4^{*}$ & $9^{* *}$ & -1 & 4 & $-3^{* *}$ & 2 & $-3.0^{* * *}$ & $-4.9^{* *}$ & $-2.8^{\star \star *}$ & $-3.2^{* *}$ \\
\hline $\begin{array}{l}40 \% \text { decrease in } \\
\text { Student-Teacher } \\
\text { Ratio }\end{array}$ & $24^{\star * *}$ & +14 & 0.6 & 0 & 0 & 0 & 4.4 & $15^{\star * *}$ & $10^{* * *}$ & -1 & -2 & 7 ** & 0 & 4.2 & -1 & 1 \\
\hline $\begin{array}{l}30 \% \text { increase in } \\
\text { Teacher Salary }\end{array}$ & 6 & -5 & 0 & -2 & 0 & 0 & $7^{* *}$ & 0 & $13^{* * *}$ & 0 & 0 & 8* & 0 & 2 & $1.8^{*}$ & $3.8^{\star *}$ \\
\hline $\begin{array}{l}\text { Mean Dep. Var. for } \\
\text { NELS-88 }\end{array}$ & 1 GLE & & $88 \%$ & & $93 \%$ & & $56 \%$ & & $42 \%$ & & $\$ 5152$ & & $\$ 26137$ & & $\$ 12.55$ & \\
\hline
\end{tabular}

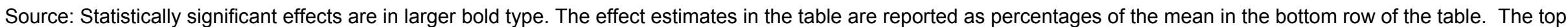

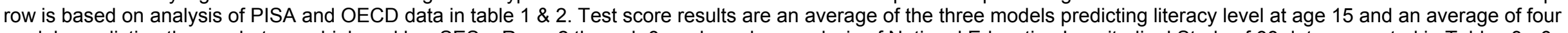

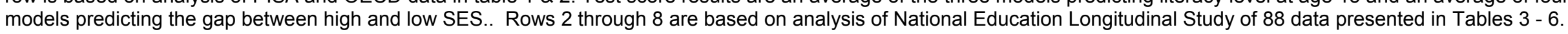

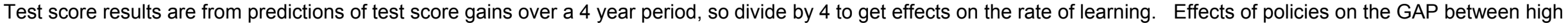

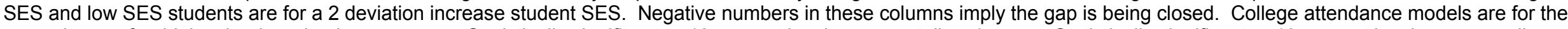

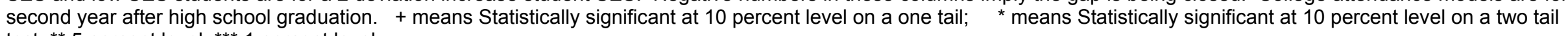
test; ${ }^{* *} 5$ percent level; *** 1 percent level. 
In the even numbered columns of the table we present estimates of the effect of each policy on the size of the GAP between the outcomes of high SES and low SES students. High status is defined as a SES index that is one standard deviation (.8 units) above the mean. Low status is one SD below the mean, so the change from low to high is 1.6 units on the SES scale. Thus a 4 credit increase in academic requirements reduces the size of the test score gap between high and low SES students by $\left[4^{*}(-.113)^{*} 1.6 /(1.965)\right]$ or -.37 GLE. Since all outcome variables are scaled so that more is better, a negative number implies that differentials between the achievements of high and low SES students are diminished by the policy or alternatively that equality of opportunity is improved. A positive number implies the policy has a more positive effect on high SES students than low SES students.

Earlier in the paper, we hypothesized that higher minimum course graduation requirements, MCEs and universal CBEEES (but not voluntary end-of-course exams) would increase resources and standards in schools serving low SES neighborhoods and induce low SES students to devote more time to learning core academic subjects. Political leaders pressing for higher standards and better funding often claim their proposal will not only increase everyone's achievement but reduce achievement gaps as well. Only two of the policies examined deliver on this compound promise: universal CBEEES and higher academic course graduation requirements. Students facing universal CBEEES have higher upper-secondary graduation rates and learn substantially more--1.2 GLE extra--and achievement gaps are reduced by 40 percent of a grade-level equivalent. Implementing universal CBEEES in the U.S. is predicted to reduce the current 2.5 GLE differential between high and low SES students by 16 percent. A four-credit increase in academic course graduation requirements is predicted to increase average achievement by .37 GLEs and to reduce the achievement gap by a similar amount. It also appears to have boosted wages and earnings in 2000 and reduced SES differentials in college attendance (but not in college completion). 
Other policies were less successful in raising achievement and enhancing equality of opportunity. Increases in state minimum total course graduation requirements did not have positive effects on any of the outcomes studied. Students from states that required an additional 4 courses to graduate did not learn more, were 4 percent less likely to attend college and earned 3 percent less both immediately after high school and seven years later. This suggests that states should reduce total course requirements, even while they increase academic course requirements.

State minimum competency exam graduation requirements had no significant relationship with mean rates of learning or achievement gaps but were associated with higher rates of college attendance and larger college attendance differentials by SES. The good news is that all types of students in MCE states earned a good deal more. Middle SES students in MCE states earned 11 percent more in 1993 and 4.2 percent more in 2000 . The short term earnings benefits of MCEs were significantly larger for low SES students. The medium term benefits of MCEs, however, were significantly smaller for low SES students.

New York's hybrid voluntary end-of-course exam/ compulsory minimum competency exam system of had a large (.55 GLE) impact on test score gains during high school. Since $8^{\text {th }}$ grade achievement levels were also higher, New York students were about one GLE ahead of students in other states by the end of high school. None of the SES interactions were statistically significant, because the small size of the sample of students from New York in NELS-88, statistical tests for a New York State effect lack power. Point estimates suggest that while high school and college graduation rates are not changed much, wages and earnings are higher 8 years after high school graduation.

Traditional spending-oriented policy recommendations like smaller class sizes and higher teacher salaries had statistically significant effects on college attendance and completion rates but no effect on high school attendance or completion or on earnings after high school (holding educational attainment constant). A 40 percent reduction in the student-teacher ratio 
increased learning during high school by roughly a quarter of a grade level equivalent and 4 year college completion by 10 percent. A 30 percent increase in teacher salary is associated with a 13 percent increase in 2 or 4 year college completion and a 10 percent increase in BAs awarded. The earnings and productivity benefits of a 4 year college education have a present discounted value exceeding $\$ 600,000$ at a $4 \%$ real discount rate. Thus the social benefits of the stimulus to college completion resulting from these traditional spending oriented policy instruments would be about $\$ 24,000$ per high school student (assuming our estimates reflect causal effects). Spending per high school student would need to rise by 20 percent, so costs are high as well. Nevertheless the four year cost-about $\$ 6000$ per student-is a good deal smaller than the benefits. Standards oriented policy proposals are much less costly and seem to produce even larger benefits. Consequently it seems inevitable that politicians will focus their energies on refining and adding to their accountability oriented policy initiatives. 


\section{Bibliography}

Association of Secondary Teachers of Ireland, Information Sheet opposing changes in Examination Systems, 1990.

Dale Ballou and Michael Podgursky, (1992) “Teacher Training and Licensure: A Layman's Guide," Better Teachers, Better Schools, Washington DC: The Fordham Foundation, 31-81.

Becker, William and Sherwin Rosen. (1992) "The Learning Effect of Assessment and Evaluation in High School." Economics of Education Review, Vol. 11, \# 2, pp.107-118.

Betts, Julian, (1998) "The Impact of Educational Standards on the Level and Distribution of Earnings." American Economic Review, vol. 88, no. 1, 266-275.

Betts, Julian and Robert Costrell. "Incentives and Equity under Standards-Based Reform " Brookings Papers on Education Policy 2001, edited by Diane Ravitch, (Washington, DC: The Brookings Institution), 9-74.

Bishop, John H.; Ferran Mane, Michael Bishop and Joan Moriarty, (2001) "The Role of End-ofCourse Exams and Minimum Competency Exams in Standards-Based Reforms" Brookings Papers on Education Policy, 267-345.

Bishop, John H.., Joan Moriarty and Ferran Mane, "Diplomas for Learning: not Seat Time," Economics of Education Review. Vol. 19, No. 3, 2000.

Bishop, John $\mathrm{H}$ and Ferran Mane. "The Impacts of Career-Technical Education on High School Labor Market Success." (with Ferran Mane) Economics of Education Review. Vol. 23, 2004, 381-402.

Bishop, John H "Drinking from the Fountain of Knowledge: Student Incentive to Study and Learn--Externalities, Information Problems and Peer Pressure." Forthcoming in the Handbook on Economics of Education, eds. Eric Hanushek and Finis Welch,

Bishop, John H "What is the Appropriate Role of Student Achievement Standards," Education in the $21^{\text {st }}$ Century: Meeting the Challenge of a Changing World, ed. Yolanda Kodrzycki, 2003, Boston, MA: Federal Reserve Bank of Boston.

Bishop, John H "School Choice and Diploma Exams," (2002) Empirical Issues in Canadian Education, Patrice de Broucker and Arthur Sweetman eds. (McGill-Queen's University Press for the John Deutsch Institute at Queen's University)

Bishop, John H. "Are National Exit Examinations Important For Educational Efficiency?" Swedish Economic Policy Review, Vol. 6, \#2, Fall 1999, 349-401.

Bishop, John H "Nerd Harassment, Incentives, School Priorities and Learning." Earning and Learning: How Schools Matter, eds Susan Mayer and Paul Peterson, (Washington, DC: Brookings Institution Press, 1999) 231-80.

Bishop, John H. The Impact of Curriculum Based External Exit Exams on Student Achievement, Journal of Economic Education, Vol 29, \# 2, Spring 1998, 171-182.

Bishop, John H.. (1996) "The Impact of Curriculum-Based External Examinations on School Priorities and Student Learning." International Journal of Education Research. , Vol 23, No. 8, 1996.

Bob, Interview conducted in Calgary Alberta in May 1996.

Carnoy, Martin and Susanna Loeb "Does External Accountability Affect Student Outcomes?" Educational Evaluation and Policy Analysis Vol. 24, \# 4, 2003.

Costrell, Robert. (1994) "A Simple Model of Educational Standards," American Economic Review, vol. 84, no. 4, (1994) pp. 956-971.

Costrell, Robert M. (1997) "Can Centralized Educational Standards Raise Welfare?" Journal of Public Economics, Vol. 65, 271-293. 
Figlio, David and Maurice Lucas. (2001) "Do High Grading Standards Affect Student Performance." Univ. of Florida, 1-38.

Hanushek Eric A. (1997) Assessing the effects of School Resources on Student Performance: An Update." Educational Evaluation and Policy Analysis, 19(2): 141-164.

Hart (Peter D.) Research Associates, (1995) "Valuable Views: A public opinion research report on the views of AFT teachers on professional issues." Washington D.C.: American Federation of Teachers, 1995, 1-24.

Hedges, Larry V., Richard Laine and Rob Greenwald. (1994) "Does Money Matter? A MetaAnalysis of Studies of Differential School Inputs on Student Outcomes." Education Researcher, 23(3), (April) :5-14.

Kang, Suk. "A Formal Model of School Reward Systems." in Incentives, Learning and Employability, edited by John Bishop, Columbus Ohio: National Center for Research in Vocational Education, 1985.

Kruger, Alan. (2000) "An Economist's View of Class Size Research." Paper presented at Conference titled "What do we Know about How to Make Small Classes Work?" Washington, DC.

Lemke, M. et al. Outcomes of Learning: Results From the 2000 Program for International Student Assessment of 15-Year-Olds in Reading, Mathematics, and Science Literacy, (Washington, DC: National Center for Educational Statistics, 2001

Lillard, Dean and Phillip DeCicca, "Higher Standards, More Dropouts? Evidence within and across Time" Economics of Education Review, 2000), pp. 1-33.

National Center for Educational Statistics. The Digest of Education Statistics: 1992. Wash. D.C.: US Department of Education, 1992.

National Center for Educational Statistics. The Condition of Education: 1993. Vol. 1, Wash. D.C.: US Department of Education, 1993.

Organization of Economic Cooperation and Development, Education at a Glance 2001, CERI, OECD, 1-406.

Organization of Economic Co-operation and Development. Literacy Skills for the World of Tomorrow: Further Results from PISA 2000. Paris, France: Organization for Economic Co-operation and Development, 2003.

Powell, Arthur; Farrar, Eleanor and Cohen, David. The Shopping Mall High School. New York, New York: Houghton Mifflin, 1985.

Wößmann, Ludger "Schooling Resources, Educational Institutions, and Student Performance: The International Evidence," Kiel Working Paper No. 983, (May 2000) Kiel Institute of World Economics, Germany, <http://www.uni-kiel.de/ifw/pub/kap/2000/kap983.htm> 188.

Wößmann, Ludger. "How Central Exams Affect Educational Achievement: International Evidence from TIMSS and TIMSS-Repeat." Paper presented at conference on: Taking Account of Accountability: Assessing Politics and Policy. Kennedy School, June 2002, 162.

Wößmann, Ludger. "Central Exams as the "Currency" of School Systems: International Evidence on the Complementarity of School Autonomy and Central Exams." DICE Report - Journal for Institutional Comparisons 1 (4): 46-56, 2003.

Wößmann, Ludger. "The Complementarity of Central Exams and School Autonomy: Theory and International Evidence." Conference on "Institutional Models in Education." in Frascati Italy, May 2004. 


\section{Endnotes}

${ }^{1}$ M. Lemke et. al., Outcomes of Learning: Results from the 2000 Program for International Student Assessment of 15-Year-Olds in Reading, Mathematics, and Science Literacy, 2001. p. 3.

${ }^{2}$ M. Lemke et. al., p. 3.

3 Nearly a third of the people who work in the Duchy of Luxembourg commute from France, Belgium and Germany so the GDP per capita figure for Luxembourg overstates the wealth and productivity of Luxembourg residents. We, therefore, felt that Belgium's GDP per capita more accurately reflected the productivity and standard of living of Luxembourg and used that figure for Luxembourg.

${ }^{4}$ Models predicting PISA scores of students who speak the school's language of instruction "most of the time at home" obtain very similar results.

${ }^{5}$ Causation may also run in a circular fashion. Some migrants may be choosing countries like Australia, New Zealand and Canada because they have CBEEES which give their children a better chance to be successful in school because the CBEEES plays to their strength-willingness to study hard.

${ }^{6}$ In models developed by Kang (1985) and Costrell (1994), some of the students faced with higher graduation standards conclude that the effort necessary to get a diploma is too great and so give up on the idea of getting a diploma. While these theoretical models associate "giving up" with dropping out of school, this is not necessarily the case. Students who believe they cannot graduate might nevertheless continue to attend high school because they enjoy socializing and playing sports or because they are learning a trade.

7 Dean Lillard and Phillip DeCicca, "Higher Standards, More Dropouts? Evidence within and across Time" (Forthcoming in Economics of Education Review, 2000), pp. 1-33.

${ }^{8}$ Minimum competency exams are additions to, not a replacement for teacher imposed standards. In a MCE regime, teachers continue to control the standards and assign grades in their own courses. Students must still get passing grades from their teachers to graduate. The MCE regime imposes an additional graduation requirement and thus cannot lower standards (Costrell 1998). The Graduate Equivalency Diploma (GED), by contrast, offers students the opportunity to shop around for an easier (for them) way to a high school graduation certificate. As a result, the GED option lowers overall standards. This is reflected in the lower wages that GED recipients command. Stephen V. Cameron and James J. Heckman, "The Nonequivalence of High School Equivalents" Working Paper \# 3804 (Boston, Mass.: National Bureau of Economic Research, 1991).

${ }^{9}$ American Federation of Teachers, Making Standards Matter:1996 (Washington, DC: American Federation of Teachers, 1996) p. 30.

10 End-of-course examination (EOCE) are similar to MCEs in the following ways. Both are set by and graded to rubrics devised by a state government or a national organization (eg. The College Board) and both carry consequences for students, the teachers and school administrators.

${ }^{11}$ Costrell, Robert M. (1998) "Can Centralized Educational Standards Raise Welfare?" Journal of Public Economics,

12 Sherman N. Tinkelman, "Regents Examinations in New York State after 100 Years" (Albany, N.Y: The University of the State of New York, The State Education Department, 1966), p. 12.

13 John H. Bishop, "Nerd Harrassment and Grade Inflation: Are College Admissions Policies Partly Responsible?" Center for Advanced Human Resources Discussion Paper \#99-14, (1999c).

${ }^{14}$ Participation rates are calculated by dividing the number of exams taken by the average enrollment per grade in high school. The New York State Education Department, "New York: The State of Learning-Statistical Profile of Public School Districts" (Albany, February, 1997). 
${ }^{15}$ Studies using detailed data from high school transcripts have demonstrated that students who take additional academic courses have bigger gains on academic tests than other students (Meyer Bishop 1999, Bishop and Mane 2005). This does not, however, guarantee that a policy that forces students to take additional academic courses will generate similar increases in academic learning. Students who take a course voluntarily are likely to learn more than students who would have preferred to take a different course or study hall instead. The students who are forced to attend the class may disrupt the learning of others or force teachers to water down the curriculum.

${ }^{16}$ Many school districts choose to set higher requirements than the state minimum. States without statewide minimum course graduation requirements were assigned a value of 13 - the lowest minimum total Carnegie unit requirement for the states with a requirement and a control variable was included in the models.

${ }^{17}$ When a student moved to another state between 10th and 12th grade an average of the MCE variables for 10th and 12th grade was used. Then the MCE variable can have three values: 1,0 or 0.5 , this last representing moving out from or in to an MCE state. When information on the state was not available for 10 th grade, residence in 12th grade was used and if that was missing as well, 8th grade residence was used. None of the states changed their policies during the 1990 to 1992 time period.

${ }^{18}$ We used a composite created by NELS staff from family income and parent's education and occupation.

${ }^{19}$ The data set and specification employed in this paper is similar to Bishop et al. (2001) "The Role of End-of-Course Exams and Minimum Competency Exams in Standards-Based Reforms." Brookings Papers on Education Policy, edited by Diane Ravitch, (Washington, DC: The Brookings Institution), 267-345. The results are also similar.

20 There were two exceptions to the generalization of identical sets of control variables. The state unemployment rates and weekly earnings in retailing were updated to 1992 and 1993 . The payoff to completing high school was not included in the model.

${ }^{21}$ M. H. Brenner. "The use of high school data to predict work performance," The Journal of Applied Psychology Vol. 52, \# 1, (1968), pp. 29-30. Department of Labor, "General Aptitude Test Battery Manual" (Superintendent of Documents, 1970). John E. Hunter, James J. Crosson and David H. Friedman, "The Validity of the Armed Services Vocational Aptitude Battery (ASVAB) For Civilian and Military Job Performance" (Department of Defense, August 1985). John Hartigan and Alexandra Wigdor, eds. Fairness in Employment Testing (Washington, D.C.: National Academy Press, 1989). Bishop, "Impact of Academic Competencies," pp. 127-194.

22 J. C. Hauser and Thomas M. Daymont, "Schooling, ability and earnings: Cross-sectional evidence 814 years after high school," Sociology of Education, Vol. 50 (July 1977), 182-206. Paul Taubman and Terence Wales, "Education as an investment and a screening device," Education, Income and Human Behavior, ed. F. T. Juster, (New York: McGraw Hill, 1975), pp. 95-122. Henry Farber and Robert Gibbons, "Learning and Wage Dynamics," Quarterly Journal of Economics (1996), pp. 1007-47.

${ }^{23}$ CBS, (1990, September 6) "America's toughest assignments: solving the education crisis." New York.

${ }^{24}$ Analyzing High School and Beyond data and controlling for college attendance and a host of other variables, Bishop, Moriarty and Mane (1998) found that females graduating from high schools with a minimum competency exam graduation requirement [student report] earned more than women graduating from schools without an MCE. Concern about the accuracy of student reports of the existence of a MCE at their high school led Bishop and Mane (1999) to reanalyze HSB data using principal reports of the existence of a MCE graduation requirement. They found even larger effects. Principal reports of a MCE graduation requirement had positive effects (significant in some but not all years) on wage rates of male and female graduates and on the earnings of graduates four and five years after graduation. The wage rate effects of MCE's appeared to be larger for students in the bottom three quarters of the test score distribution. 